\title{
OSADNICTWO PÓŹNOMEOZOLITYCZNE NA STANOWISKU 29 W KOPANICY, GM. SIEDLEC
}

\author{
LATE MESOLITHIC SETTLEMENT AT KOPANICA, \\ SITE 29, SIEDLEC COMMUNE
}

\author{
Przemysław Bobrowski \\ Instytut Archeologii i Etnologii PAN, Ośrodek Studiów Pradziejowych i Średniowiecznych \\ ul. Rubież 46, 61-612 Poznań, Poland \\ boberpusz@gazeta.pl \\ Iwona Sobkowiak-Tabaka \\ Instytut Archeologii i Etnologii PAN, Ośrodek Studiów Pradziejowych i Średniowiecznych \\ ul. Rubież 46, 61-612 Poznań, Poland \\ iwona.sobkowiak@iaepan.poznan.pl
}

\begin{abstract}
Kopanica, site 29, is situated on the eastern edge of a former glacial trough, which now channels the Obra River north, and the latitudinal Warsaw-Berlin ice marginal valley. 2003 archaeological excavations at the site revealed evidence of intensive Late Mesolithic settlement. Trenches located on the sandy and gravel fluvial terrace of the Obra and in the zone of biogenic sediments yielded a substantial flint assemblage and remains of a dwelling structure sunken into the ground. The structure was radiocarbon dated owing to a fragment of a burnt animal bone from the fill deposit. The radiocarbon date coincides with the results of technological and typological analyses of the flint inventory. The Mesolithic settlement at the site can accordingly be attributed to a stay of a group representing the Chojnice-Pieńków (post-Maglemose) culture in the second half of the Atlantic period.
\end{abstract}

KEY WORDS: Atlantic, Late Mesolithic, Chojnice-Pieńki culture, dwelling structure

\section{WSTĘP}

Stanowisko 29 w Kopanicy położone jest na wschodnim brzegu dawnej rynny glacjalnej, którą dziś przepływa Północny Kanał Obry i w której leżą jeziora zbąszyńskie. Zlokalizowane jest na północno-zachodnim krańcu dzisiejszej wsi, około 


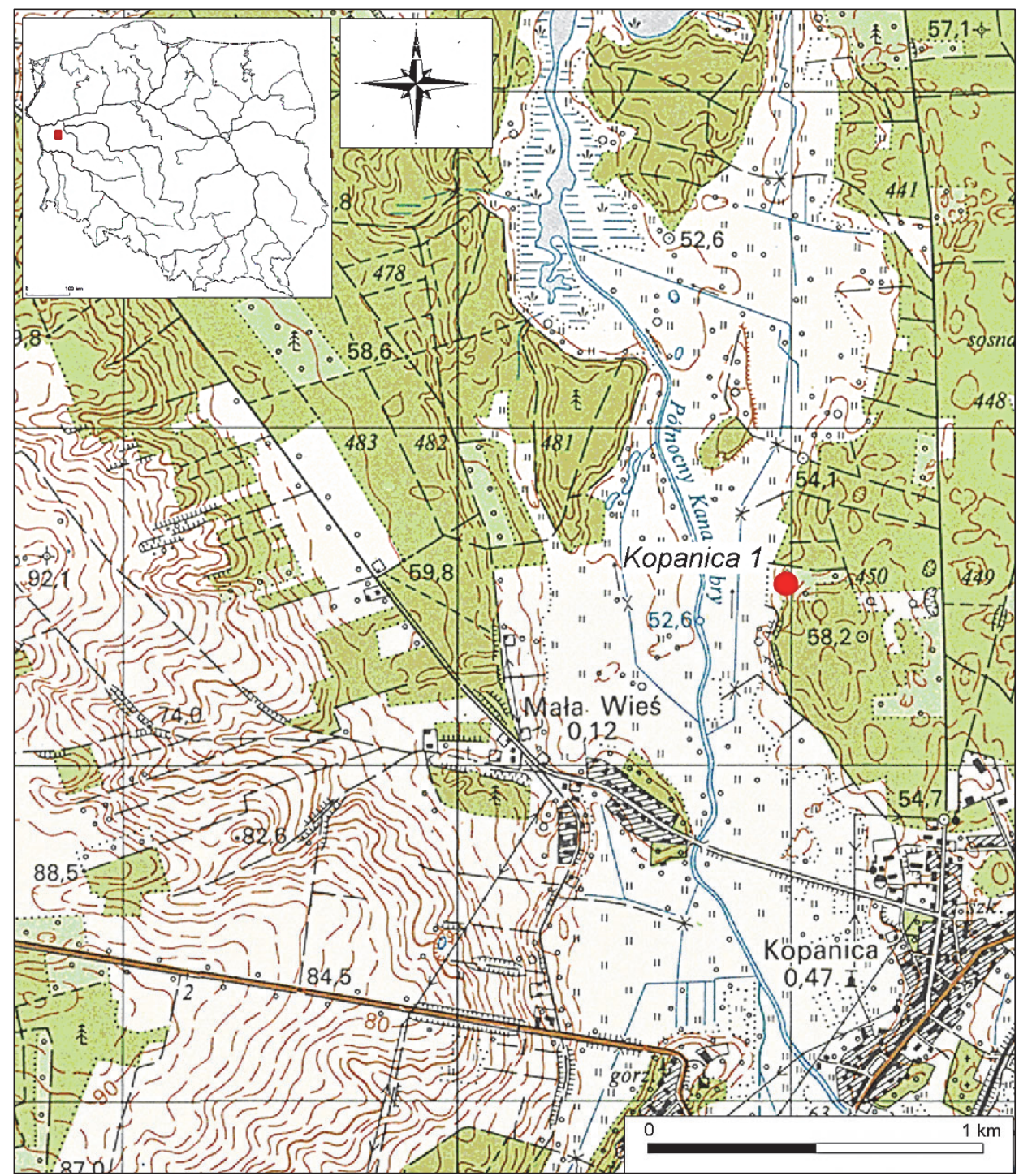

Ryc. 1. Kopanica, stan. 29. Położenie stanowiska na mapie w skali 1:10 000 (rys. P. Wiktorowicz)

Fig. 1. Kopanica, site 29. Location of the site on a 1:10 000 map (drawn by P. Wiktorowicz)

$1 \mathrm{~km}$ od jej centrum, 0,8 km na północ od szosy z Kopanicy do Wąchabna i 0,23 km od dzisiejszego koryta rzeki (ryc. 1). Stanowisko rozciąga się na kulminacji i stoku piaszczysto-żwirowej terasy nadzalewowej Obry. Jego obszar został określony na podstawie dyspersji materiału zabytkowego na powierzchni oraz serii niewielkich sondaży na powierzchni 0,5 ha. W części wschodniej stanowisko jest zalesione, 
natomiast od zachodu przylegają do niego, leżące na terasie zalewowej, łąki i pastwiska (ryc. 2).

Omawiany teren położony jest na styku dwóch mikroregionów, tj. tzw. Bruzdy Zbąszyńskiej, wchodzącej w skład makroregionu Pojezierza Lubuskiego oraz Kotliny Kargowskiej będącej częścią Pradoliny Warciańsko-Odrzańskiej (Warszawsko-Berlińskiej). Bruzda Zbąszyńska jest szerokim obniżeniem między Pojezierzem Łagowskim a Pojezierzem Poznańskim, wykorzystywanym przez Obrę, która bifurkuje w Pradolinie Warciańsko-Odrzańskiej i jednym z ramion kieruje się na zachód, do Odry, a drugim na północ, do Warty. We wschodniej części Kotliny Kargowskiej wody Obry rozdzielone są na trzy kanały, z których dwa - Środkowy i Północny po połączeniu kierują się do rynny jezior zbąszyńskich (Bruzdą Zbąszyńską) (Kondracki 2009, s. 136, 149).

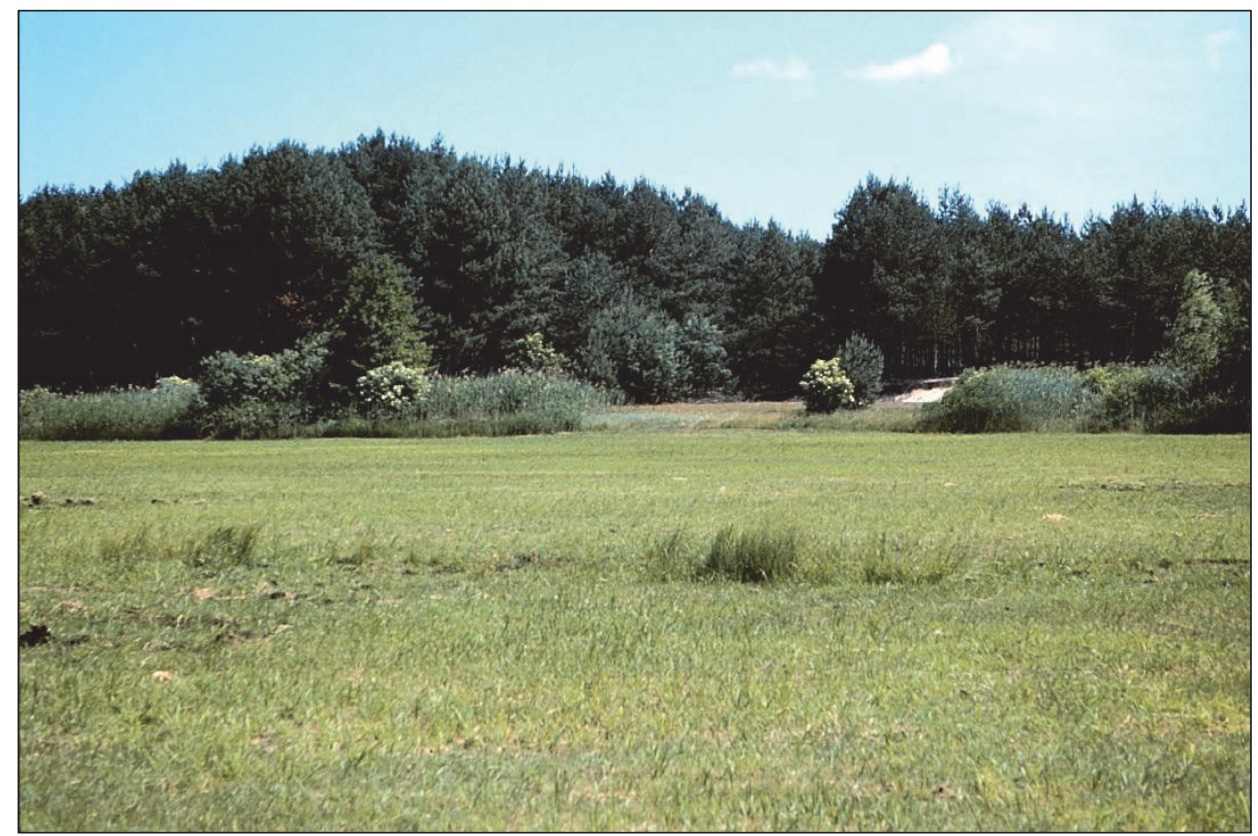

Ryc. 2. Kopanica, stan. 29. Widok na stanowisko od zachodu (fot. P. Bobrowski)

Fig. 2. Kopanica, site 29. West view of the site (photo P. Bobrowski)

\section{STAN BADAŃ}

Stanowisko zostało odkryte w latach 90. XX w. w trakcie badań związanych z programem Archeologicznego Zdjęcia Polski (arkusz 58-13). Bezpośrednią przyczyną podjęcia przez Przemysława Bobrowskiego ratowniczych badań na stanowi- 
sku była informacja z Nadleśnictwa w Wolsztynie o systematycznej dewastacji stanowiska wskutek nielegalnego poboru piasku. Dodatkowym impulsem była planowana przez Urząd Gminy w Siedlcu budowa na jego obszarze oczyszczalni ścieków. Pierwszą prospekcję powierzchni stanowiska wykonano jesienią $2002 \mathrm{r}$. W tym czasie przeprowadzono także serię wierceń na stanowisku i przylegającym do niego torfowisku. Regularne badania wykopaliskowe podjęto w czerwcu i lipcu $2003 \mathrm{r}^{1}$ Prace prowadzone na stanowisku miały charakter dwuetapowy. W pierwszym przeprowadzono szczegółowe rozpoznanie archeologiczne na powierzchni kolizji stanowiska archeologicznego z planowaną inwestycją, z pominięciem wschodniej części stanowiska przylegającej do działki leśnej, która została wcześniej zniszczona przez

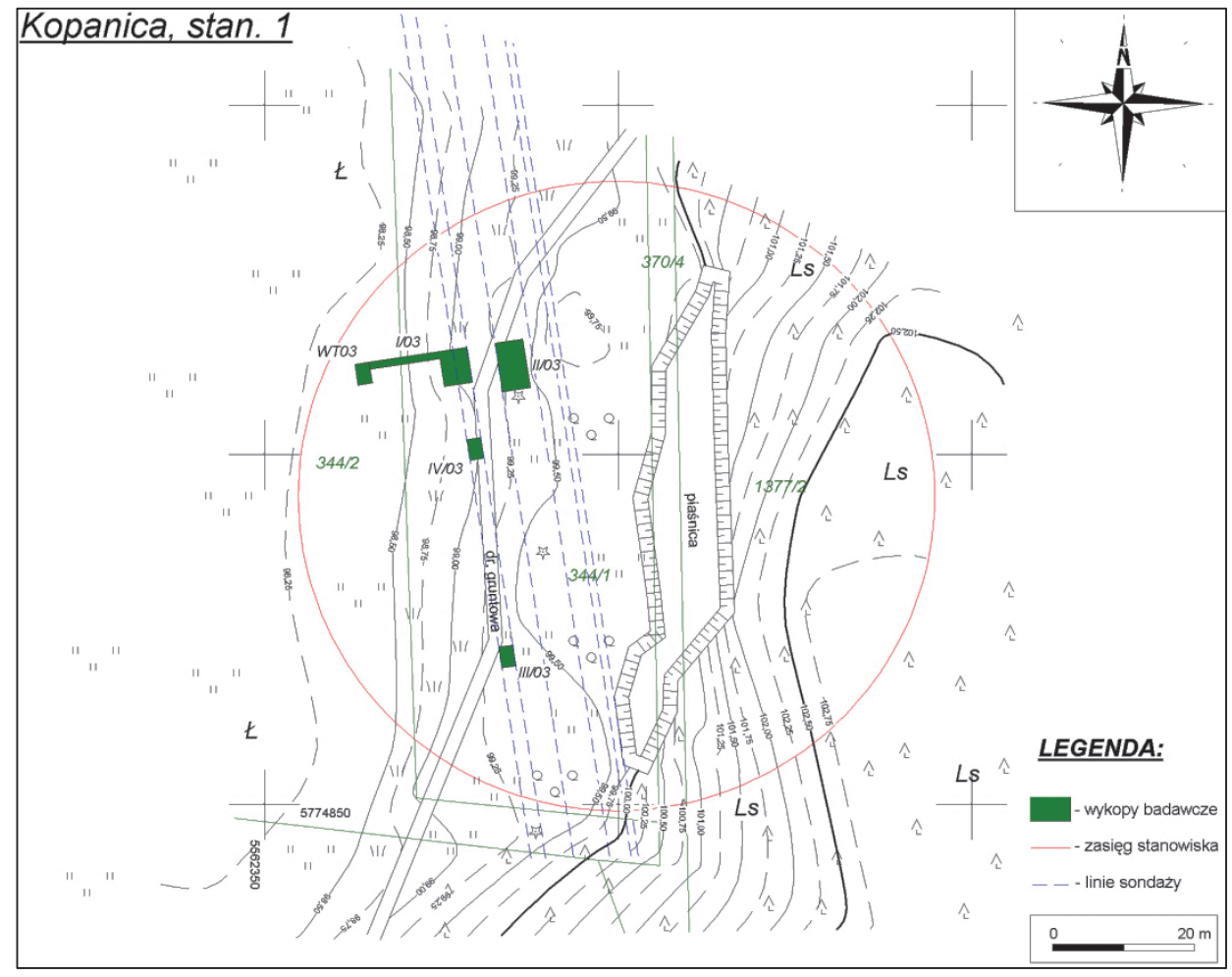

Ryc. 3. Kopanica, stan. 29. Lokalizacja wykopów na stanowisku na tle mapy sytuacyjno-wysokościowej w skali 1:1000 (rys. P. Wiktorowicz)

Fig. 3. Kopanica, site 29. Location of trenches at the site against the 1:1000 topographic map (drawn by P. Wiktorowicz)

\footnotetext{
${ }^{1}$ Pracami archeologicznymi z ramienia Instytutu Archeologii i Etnologii PAN oraz Poznańskiego Towarzystwa Prehistorycznego kierował Przemysław Bobrowski. Badania finansowane były w całości przez Urząd Gminy w Siedlcu.
} 
nielegalne wybierzysko piasku. Prace te polegały na wykonaniu sieci ponad 200 niewielkich wykopów sondażowych o wymiarach $0,3 \times 0,3 \mathrm{~m}$ i głębokości wahającej się w zależności od układu i miąższości warstw naturalnych od 0,5 do 0,8 m. Wykopy sondażowe wykonano w sześciu równoległych rzędach zorientowanych wzdłuż osi N-S (ryc. 3). Na podstawie dyspersji artefaktów krzemiennych w poszczególnych przypadkach możliwe było określenie stref ich koncentracji. Poczynione obserwacje pokrywały się z wynikami wcześniejszej prospekcji stanowiska, w czasie której najwięcej artefaktów krzemiennych znaleziono na kulminacji terasy nadzalewowej rzeki (obecnie częściowo zalesionej). W efekcie przeprowadzonych prac pozyskano łącznie 294 artefakty krzemienne, w tym 10 rdzeni, 19 narzędzi retuszowanych i charakterystycznych odpadów z ich produkcji, a także 262 okazy debitażu i 3 bryłki surowca. Wśród diagnostycznych form narzędziowych było 6 zbrojników (m.in. dwa trapezy, dwa trójkąty, tylczak łukowy - por. ryc. 8:5-6) oraz fragment (trzonek) liściaka bez łuskania strony spodniej trzonka, tzw. ahrensburskiego (ryc. 8:7).

$\mathrm{W}$ drugim etapie prac na powierzchni terasy nadzalewowej założono cztery wykopy badawcze I/03, II/03, III/03 i IV/03 (zorientowane dłuższym bokiem równolegle do osi N-S) oraz niewielki wykop torfowy WT I/03 na powierzchni terasy zalewowej rzeki, w strefie występowania osadów biogenicznych (ryc. 3). Eksplorację prowadzono metodą ław i kwadr warstwami mechanicznymi o miąższości $5-10 \mathrm{~cm}$, w ramach warstw naturalnych.

\section{STRATYGRAFIA STANOWISKA}

Północne krawędzie wykopów WT I/03, I/03 i II/03 tworzyły jedną linię, dzięki czemu uzyskano długi, liczący $24 \mathrm{~m}$ profil stanowiska wzdłuż osi WE (por. ryc. 4). Pod warstwą humusu (1), którego miąższość wahała się od $15 \mathrm{~cm}$ w części zachodniej do $25 \mathrm{~cm}$ w części wschodniej (miejscami $50 \mathrm{~cm}$ na samej krawędzi wykopu) zaobserwowano warstwę jasnożółtego drobnoziarnistego piasku ilastego (2) oraz iluwium w postaci szarego drobnoziarnistego piasku z domieszką próchnicy (4). Obie warstwy miały maksymalną miąższość od 60 do $70 \mathrm{~cm}$. W obrębie wykopu I/03 były one przedzielone warstwą najwyższego poziomu torfów, zaobserwowanego w wykopie WT/03 (3). W ramach wykopu torfowego zaobserwowano kilka poziomów torfu o zróżnicowanej barwie i stopniu rozłożenia. Bezpośrednio pod warstwą humusu (1) oraz piasku (2) wyróżniono poziom jasnobrunatnego słabo rozłożonego torfu o miąższości $40 \mathrm{~cm}$ (3), ciemnobrunatnego silnie rozłożonego torfu o miąższości $30 \mathrm{~cm}$ (5) i żółtawego słabo rozłożonego torfu o miąższości około $50 \mathrm{~cm}$ (6). Poniżej zarejestrowano poziom czarnego silnie rozłożonego torfu o miąższości $25 \mathrm{~cm}$ (7) i poziom brunatnego dobrze rozłożonego torfu o miąższości $90 \mathrm{~cm}(8)$. 


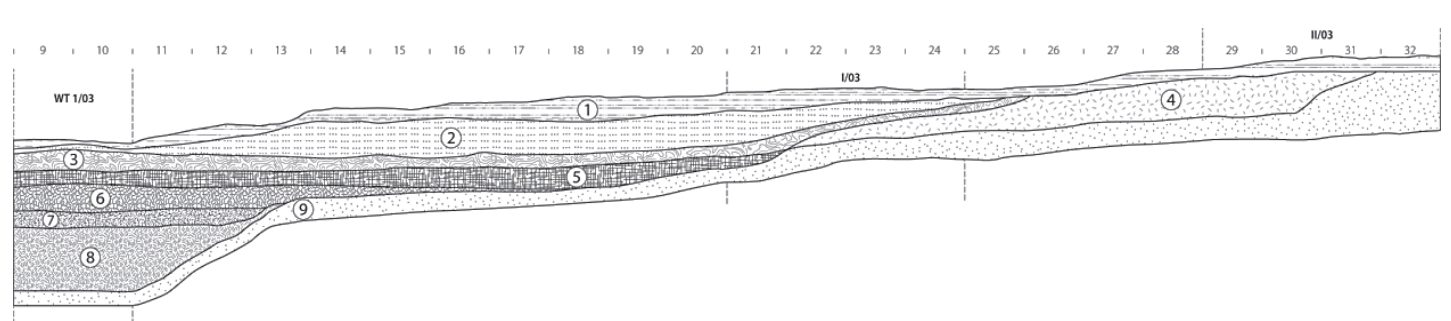

Ryc. 4. Kopanica, stan. 29, gm. Siedlec. Profil północny wykopów WT I/03, I/03, II/03. 1 - humus, 2 - jasnożółty drobnoziarnisty piasek ilasty, 3 - jasnobrunatny słabo rozłożony torf, 4 - szary drobnoziarnisty piasek z domieszką próchnicy, 5 - ciemnobrunatny silnie rozłożony torf, 6 - żółtawy słabo rozłożony torf, 7 - czarny silnie rozłożony torf, 8 - brunatny dobrze rozłożony torf, 9 - jasnoszary drobnoziarnisty żwir

Fig. 4. Kopanica, site 29, Siedlec Commune. Northern profile of WT I/03, I/03 and II/03 trenches. 1 - humus, 2 - pale yellow fine-grained clayey sand, 3 - light brown weakly decomposed peat, 4 - grey fine-grained sand mixed with humus, 5 - dark brown highly decomposed peat, 6 - yellowish weakly decomposed peat, 7 - black highly decomposed peat, 8 - dark brown well-decomposed peat, 9 - light grey fine-grained gravel

Całość podścielona była jasnoszarymi drobnoziarnistymi żwirami (9), które w części zachodniej (w obrębie wykopu WT/03) wystąpiły na głębokości około $260 \mathrm{~cm}$ od powierzchni, a we wschodniej zalegały płytko, bezpośrednio pod warstwą humusu.

\section{WYKOPY BADAWCZE}

Największy wykop badawczy, oznaczony jako I/03, miał łączną powierzchnię $30 \mathrm{~m}^{2}$, a jego główna część o wymiarach $4 \times 5 \mathrm{~m}$ była położona na samej krawędzi terasy nadzalewowej. Od jego NW narożnika wytyczono wąski i długi (o wymiarach $1 \times 10 \mathrm{~m}$ ) przekop łączący się z wykopem torfowym położonym na powierzchni terasy zalewowej w strefie występowania osadów biogenicznych. Eksplorację w ramach wykopu prowadzono do głębokości około $0,8-1 \mathrm{~m}$. W jej trakcie nie zarejestrowano żadnych nieruchomych obiektów archeologicznych, natomiast pozyskano liczny materiał zabytkowy, w tym 791 artefaktów krzemiennych oraz 8 kości zwierzęcych²

\footnotetext{
${ }^{2} \mathrm{~W}$ warstwie humusu i bezpośrednio pod nią zarejestrowano około 1000 drobnych fragmentów nowożytnej ceramiki naczyniowej (XVIII-XX w.), 2 przedmioty kamienne, niewielką bryłkę ochry, monetę - srebrny półgrosz Fryderyka II bity dla Brandenburgii przez mennicę w Berlinie (identyfikację monety przeprowadził mgr Arkadiusz Tabaka, któremu autorzy składają podziękowanie). Ponadto w wykopie I/03, w warstwie do głębokości $30 \mathrm{~cm}$, występowały kości zwierzęce. Trzy fragmenty to kości dzika (strzałkowa, łokciowa, śródręcza), należące prawdopodobnie do osobnika subadultus. Na jednej z nich zaobserwowano ślady porcjowania. Kolejna kość - żebro (gatunek nieokreślony) - nosiła ślady porcjowania. Wszystkie znajdowały się w warstwie na głębokości $20-30 \mathrm{~cm}$. W wyżej położonej warstwie znaleziono człon palcowy lisa (?), kość śródręcza świni oraz 2 bliżej nieokreślone fragmenty
} 
Eksplorację prowadzono warstwami mechanicznymi o miąższości $10 \mathrm{~cm}$, osiągając calec w postaci jasnoszarego drobnoziarnistego żwiru na głębokości ponad $260 \mathrm{~cm}$ od powierzchni. Cztery wyroby krzemienne wystąpiły wyłącznie w górnych warstwach wykopu (na głębokości około 10-20 cm). Nie stwierdzono natomiast obecności żadnych pozostałości artefaktów z surowców organicznych czy węgli drzewnych, które umożliwiłyby bardziej precyzyjne datowanie poszczególnych poziomów torfowych.

W dwóch mniejszych wykopach III/03 oraz IV/03 (o wymiarach $3 \times 2 \mathrm{~m}$ ), założonych $\mathrm{w}$ miejscach mniejszej koncentracji materiału zabytkowego, na krawędzi terasy nadzalewowej, artefakty występowały do głębokości $40-60 \mathrm{~cm}$, a calec w postaci szarego drobnoziarnistego piasku zmieszanego ze żwirami osiągnięto na głębokości $80-100 \mathrm{~cm}$ od powierzchni. W wykopach nie zaobserwowano żadnych nieruchomych obiektów archeologicznych. W ramach wykopu III/03 zarejestrowano łącznie 86 artefaktów krzemiennych oraz 31 fragmentów nowożytnej ceramiki naczyniowej, natomiast $\mathrm{z}$ wykopu IV/03 pochodziły 252 wyroby krzemienne oraz 40 analogicznie datowanych fragmentów nowożytnych naczyń. Ponadto w każdym z wykopów znaleziono po jednym niediagnostycznym fragmencie kości zwierzęcej.

\section{ŚLADY OBOZOWISKA PÓŹNOMEZOLITYCZNEGO}

W obrębie wykopu II/03 odkryto zapewne tylko fragment obozowiska mezolitycznych łowców-zbieraczy. Wykop o powierzchni $28 \mathrm{~m}^{2}$ założono po wschodniej stronie współczesnej drogi polnej. Eksplorację prowadzono do osiągnięcia calca w postaci jasnoszarego drobnoziarnistego żwiru, do głębokości od $80 \mathrm{~cm}$ (we wschodniej części wykopu) i do $120 \mathrm{~cm}$ (w części zachodniej). Łącznie w wyniku badań nawarstwień pozyskano 890 artefaktów krzemiennych, 202 fragmenty naczyń ceramicznych oraz 7 fragmentów silnie rozdrobnionych i zniszczonych kości. W zdecydowanej większości była to nowożytna ceramika naczyniowa (XVIII-XX w.). Zarejestrowano jednak kilkanaście fragmentów ceramiki kultury łużyckiej ${ }^{3}$. Dyspersję artefaktów krzemiennych w ramach wykopu prezentuje ryc. 5 .

\section{OBIEKT MIESZKALNY}

W południowej części wykopu, pod humusem, na poziomie $25 \mathrm{~cm}$ od powierzchni, na tle jasnożółtego drobnoziarnistego ilastego piasku zaobserwowano obiekt o nie-

\footnotetext{
kości noszące ślady przepalenia w ogniu. Kości zwierzęce analizował prof. dr hab. Daniel Makowiecki z UMK, któremu autorzy dziękują.

${ }^{3}$ Analizę wykonał dr Krzysztof Szamałek, któremu autorzy opracowania składają serdeczne podziękowania.
} 


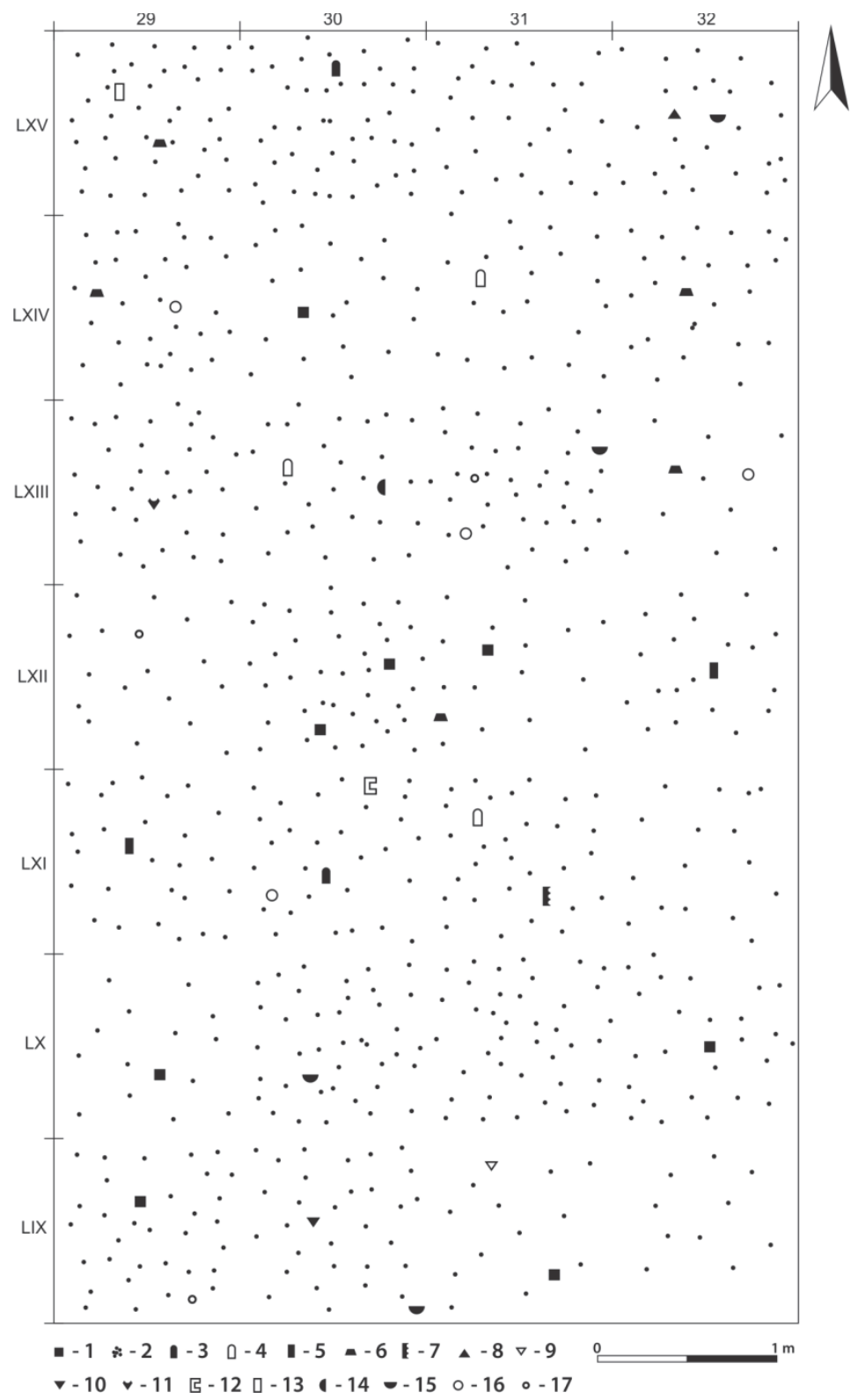

Ryc. 5. Kopanica, stan. 29, gm. Siedlec. Dyspersja artefaktów w wykopie II/03. 1 - rdzeń, 2 - debitaż, 3 - drapacz, 4 - skrobacz, 5 - tylczak, 6 - trapez, 7 - narzędzie zę̧bate, 8 - trójkąt, 9 - przekłuwacz, 10 - wiertnik, 11 - ciosak, 12 - obłęcznik, 13 - rylec, 14 - wiórek retuszowany, 15 - wiór retuszowany, 16 - odłupek retuszowany, 17 - okrzesek retuszowany (rys. P. Szejnoga)

Fig. 5. Kopanica, site 29, Siedlec Commune. Dispersion of artefacts in trench II/03. 1 - core, 2 - debitage, 3 - endscraper, 4 - scraper, 5 - backed piece, 6 - trapeze, 7 - denticulate tool, 8 - triangle, 9 - perforator, 10 - borer, 11 - tranchet, 12 - notch, 13 - burin, 14 - retouched bladelet, 15 - retouched blade, 16 - retouched flake, 17 - retouched chip (drawn by P. Szejnoga) 

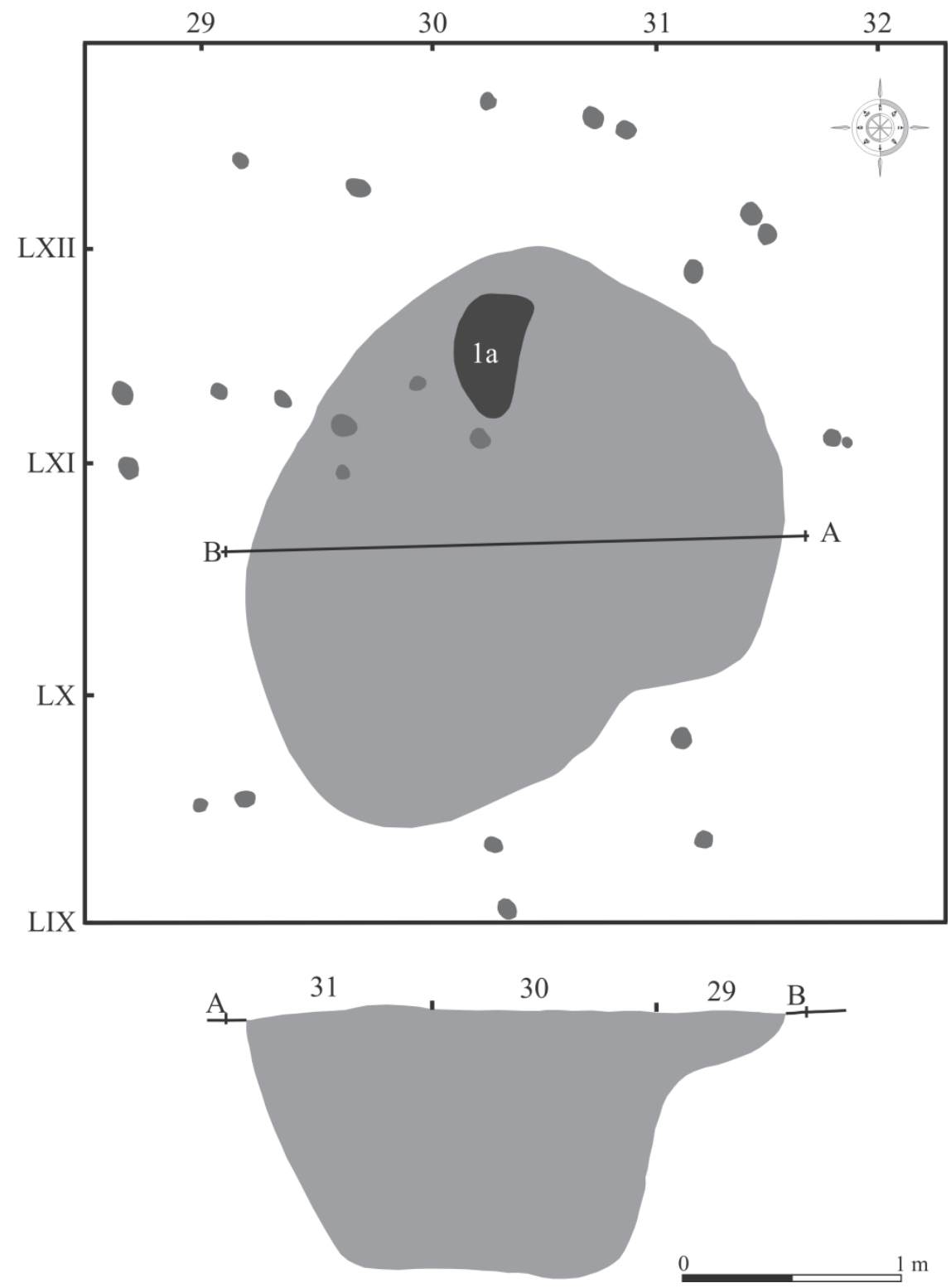

Ryc. 6. Kopanica, stan. 29, gm. Siedlec. Rzut poziomy i profil S obiektu mieszkalnego w wykopie II/03. 1 - rdzeń, 2 - debitaż, 3 - drapacz, 4 - skrobacz, 5 - tylczak, 6 - trapez, 7 - narzędzie zębate, 8 - trójkąt, 9 - przekłuwacz, 10 - wiertnik, 11 - ciosak, 12 - obłęcznik, 13 - rylec, 14 - wiórek retuszowany, 15 - wiór retuszowany, 16 - odłupek retuszowany, 17 - okrzesek retuszowany (rys. P. Szejnoga)

Fig. 6. Kopanica, site 29, Siedlec Commune. Ground plan and S cross-section through the dwelling structure in trench II/03. 1 - core, 2 - debitage, 3 - endscraper, 4 - scraper, 5 - backed piece, 6 - trapeze, 7 - denticulate tool, 8 - triangle, 9 - perforator, 10 - borer, 11 - tranchet, 12 - notch, 13 - burin, 14 - retouched bladelet, 15 - retouched blade, 16 - retouched flake, 17 - retouched chip (drawn by P. Szejnoga) 
regularnym owalnym kształcie w rzucie poziomym (oznaczony jako obiekt 1). Miał on wymiary $220 \times 200 \mathrm{~cm}$. W przekroju pionowym obiekt miał kształt odwróconego trapezu (lekko asymetryczny), a jego miąższość wynosiła około $110 \mathrm{~cm}$. Wypełnisko obiektu było jednorodne i stanowił je ciemnoszary drobnoziarnisty piasek z domieszką próchnicy oraz silnie rozdrobnionych węgli drzewnych. Granica obiektu, bardzo czytelna w części wschodniej profilu, w kierunku zachodnim uległa stopniowemu rozmyciu (ryc. 6-7). W stropie tego obiektu (w północnej części) rysował się mniejszy obiekt (o ciemniejszym zabarwieniu) o owalnym w rzucie poziomym kształcie i wymiarach $60 \times 40 \mathrm{~cm}$ (oznaczony jako obiekt 1a). W rzucie pionowym był on nieckowaty, lekko asymetryczny, a jego wypełnisko stanowił drobnoziarnisty piasek silnie nasycony rozdrobnionymi węglami drzewnymi, co sugeruje, że obiekt pełnił funkcję ogniska. W jego bezpośrednim sąsiedztwie, od zachodu, zaobserwowano również cztery dołki posłupowe o kolistym przekroju poziomym, o średnicy od 8 do $18 \mathrm{~cm}$, o V-kształtnym przekroju pionowym i głębokości od 10 do $60 \mathrm{~cm}$. Na poziomie około $35 \mathrm{~cm}$ od współczesnej powierzchni, w obrębie wykopu, wystąpiło kolejnych 20 dołków posłupowych rozmieszczonych na planie kolistym w regularnych odstępach, tworzących dwa zewnętrzne pierścienie wokół obiektu nr 1. Dołki położone od strony NE w zewnętrznym pierścieniu zblokowane były po dwa (ryc. 6-7). Wszystkie miały średnicę od kilku do $20 \mathrm{~cm}$ i przekrój pionowy U- lub V-kształtny. Ich miąższość wahała się od 10 do ponad $50 \mathrm{~cm}$ głębokości, a wypełnisko wszystkich było jednorodne - stanowił je ciemnoszary drobnoziarnisty piasek z domieszką próchnicy.

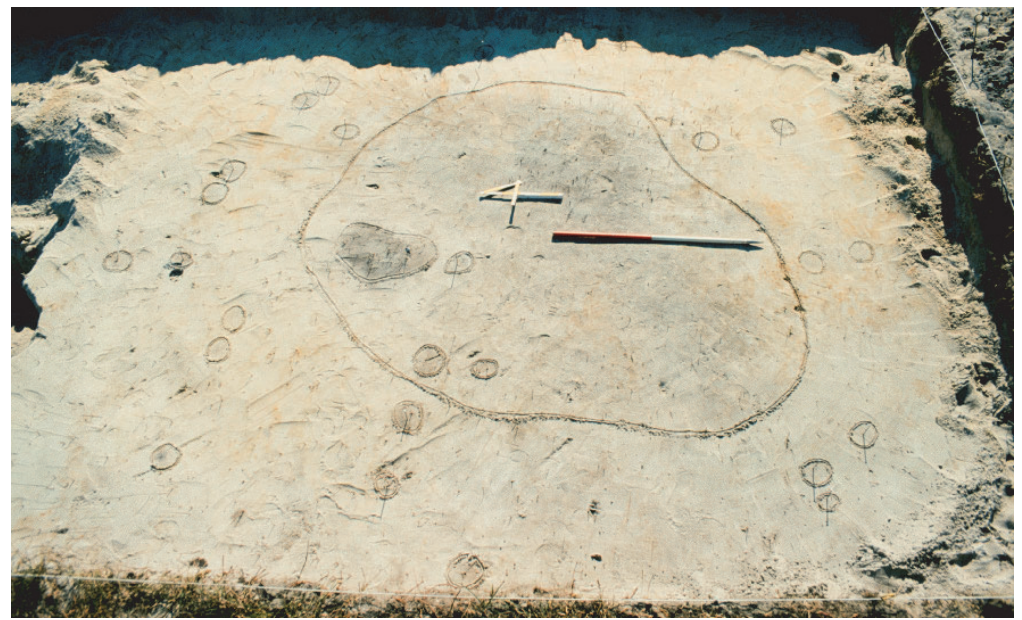

Ryc. 7. Kopanica, stan. 29, gm. Siedlec. Rzut poziomy obiektu mieszkalnego $\mathrm{nr} 1 \mathrm{na}$ poziomie $40 \mathrm{~cm}$, licząc od współczesnej powierzchni (fot. P. Bobrowski)

Fig. 7. Kopanica, site 29, Siedlec Commune. Ground floor of the dwelling structure no. $140 \mathrm{~cm}$ down from the present surface (photo P. Bobrowski) 
Z obiektu $\mathrm{nr} 1$ (na poziomach od 30 do $90 \mathrm{~cm}$ poniżej powierzchni) pozyskano 77 artefaktów krzemiennych, wśród których był 1 odłupek retuszowany, 5 wiórów i 7 odłupków oraz 64 drobne łuski i okruchy. Ponadto w północnej części obiektu, na głębokości $70 \mathrm{~cm}$ od powierzchni, zarejestrowano pojedynczy fragment kości zwierzęcej określonej gatunkowo jako jeleniowate (fragment bloczka końca dalszego kości), noszący ślady przepalenia.

Analiza wzajemnej relacji stratygraficznej obiektów nie wykazała związków funkcjonalnych między obiektami 1 i 1a. Ognisko (obiekt 1a) zostało ewidentnie wkopane w strop obiektu nr 1 i zagłębione na około $30 \mathrm{~cm}$. Potwierdzeniem tego faktu są również dwa oznaczenia radiowęglowe. Pierwsza, wykonana $\mathrm{z}$ węgli drzewnych z ogniska, wskazuje na jego wczesnośredniowieczny wiek ( $970 \pm 30 \mathrm{BP}$; Poz-9015), natomiast druga, uzyskana $\mathrm{z}$ fragmentu kości znalezionej w obiekcie nr 1 jest o kilka tysiącleci wcześniejsza - 5870 $\pm 40 \mathrm{BP}$ (Poz-3373).

Układ dołków posłupowych, zwłaszcza tych regularnie rozmieszczonych wokół obiektu nr 1, pozwala na założenie związku funkcjonalnego tych obiektów. Mamy tu prawdopodobnie do czynienia $\mathrm{z}$ niewielkim obiektem mieszkalnym. Stosunkowo duża miąższość obiektu i zagłębienie w ziemię sugeruje, że była to półziemianka. $\mathrm{Z}$ drugiej strony niewielkie rozmiary (całkowita średnica obiektu wynosiła około 3,6 m) oraz rozkład dołków posłupowych może świadczyć o konstrukcji typu szałasu. Wspomniane zblokowanie dołków zlokalizowanych po stronie NE obiektu, w zewnętrznym pierścieniu, sugeruje wejście do obiektu z tego kierunku.

Z terenu Niziny Polskiej znane są nieliczne stanowiska mezolityczne (około 10), na których odkryto obiekty o charakterze mieszkalnym. Część z nich zostało określonych w literaturze jako ziemianki/półziemianki: Tanowo, stan 3, pow. policki; Rotnowo, stan. 18 i Płoty-Budziszcze, stan. 2, pow. gryficki (Galiński 2007, s. 112-113); Ośno Lubuskie, stan. 7, pow. słubicki (Kabaciński, Sobkowiak-Tabaka 2010, s. 63-66); Pomorsko, stan 1, pow. zielonogórski (Kobusiewicz, Kabaciński 1991, Kabaciński 2008, s. 132-133); Siedlnica, stan. 6, pow. wschowski, Bartków, stan. 7, pow. górowski (Bagniewski 1977); Jastrzębia Góra, stan. 4, pow. pucki (Domańska 1992, Ruta 1997); Mszano, stan. 14, pow. brodnicki (Marciniak 1998) czy Miłuki, stan. 4, pow. ełcki (Brzozowski, Siemaszko 1995). Inne uznano za obiekty naziemne - szałasy: Łęczyn, stan. 13, pow. strzelecko-drezdenecki (Bagniewski 1999); Swornegacie, stan. 6, pow. chojnicki (Bagniewski 1979, 1987); Czeladź Wielka, stan. I, pow. górowski (Bagniewski 1977) i 2 obiekt ze stanowiska w Ośnie Lubuskim, stan. 7 (Kabaciński, Sobkowiak-Tabaka 2010, s. 68-69). Elementami różnicującymi poszczególne typy były zarówno stopień zagłębienia obiektu w ziemię, wielkość, jak i obecność elementów konstrukcyjnych, takich jak dołki posłupowe, układy kamieni czy rowy fundamentowe. Biorąc pod uwagę rozmiary i zarys w rzucie poziomym, obiekt mieszkalny z Kopanicy znajduje bliskie analogie na stanowisku w Ośnie Lubuskim. Oba obiekty mieszkalne miały owalny zarys w rzucie poziomym i wymiary $310 \times 246 \mathrm{~cm}$ oraz $200 \times 190 \mathrm{~cm}$. Różnily się tylko 
stopniem zagłębienia w ziemię (odpowiednio 60 i $30 \mathrm{~cm}$ ). Okres funkcjonowania obu obiektów na podstawie datowań radiowęglowych określono na przełom okresu borealnego i atlantyckiego (Kabaciński, Sobkowiak-Tabaka 2010, s. 63-74). Podobny zarys i wymiary miał również obiekt mieszkalny z Tanowa, wiązany z osadnictwem kompleksu Duvensee i datowanym na okres atlantycki (Galiński 2007, s. 113). Pod względem zarówno formalnym, jak i konstrukcyjnym bliską analogią jest zapewne obiekt ze stanowiska w Mszanie. Półziemianka miała w rzucie poziomym zarys kolisty o średnicy $315 \mathrm{~cm}$ i była otoczona pozostałościami 90 dołków posłupowych. Obiekt zagłębiony był w ziemię na $40 \mathrm{~cm}$. Do wnętrza prowadziło „korytarzowe" wejście (o długości $200 \mathrm{~cm}$ ) od strony NE (Marciniak 1998). Podobny obiekt o kolistym rzucie poziomym, średnicy ok. $400 \mathrm{~cm}$, znacznie zagłębiony w ziemię (ok. $75 \mathrm{~cm}$ ) pochodzi ze stanowiska I w Czeladzi Wielkiej (Bagniewski 1977). Najbliższą analogię zarówno pod względem formalnym, jak i konstrukcyjnym dla obiektu w Kopanicy odkryto na stanowisku Nivå 10 na Zelandii (Dania), gdzie odsłonięto obiekt półziemiankowy o kształcie kolistym i średnicy $240 \mathrm{~cm}$. W jego wnętrzu oraz na obrzeżach zarejestrowano dołki posłupowe o średnicy 4-15 $\mathrm{cm}$ i głębokości $15-20 \mathrm{~cm}$. Wypełnisko obiektu stanowił ciemny piasek (zabarwiony rozdrobnionymi węglami drzewnymi), a w jego centrum znajdowało się palenisko, w którym zarejestrowano szczątki zwierzęce oraz ości ryb. Obiekt związany jest z osadnictwem społeczności kultury Kongemose i datowany radiowęglowo na okres atlantycki (Jensen 2009).

\section{MATERIALY KRZEMIENNE}

Materiały zabytkowe, pochodzące ze wszystkich wykopów badawczych, były rozłożone równomiernie, nie tworząc wyraźnych koncentracji. Dotyczy to zarówno debitażu, jak i rdzeni oraz narzędzi. Podobny był rozkład materiału krzemiennego noszącego ślady przegrzania w ogniu. Krzemienie występowały zarówno w wierzchniej warstwie próchnicy, jak i poniżej w warstwie iluwialnej. Analiza profilu stanowiska (por. ryc. 4) pokazuje, że pierwotny poziom użytkowy, związany z zarejestrowaną na stanowisku wytwórczością krzemieniarską, odsłonięto w ramach wykopu II/03 i tylko we wschodniej części wykopu I/03 (warstwa 4, 9), natomiast zachodnia część wykopu I/03 oraz III/03 i IV/03 znalazły się w strefie intensywnych spływów z wyżej położonych partii stanowiska.

Łącznie we wszystkich wykopach na stanowisku w Kopanicy zarejestrowano 2022 zabytki krzemienne, w tym 1 bryłkę surowca, 27 rdzeni, 75 narzędzi oraz 1919 okazów debitażu. Inwentarz krzemienny został opracowany na podstawie metody typologii dynamicznej (por. Schild, Marczak, Królik 1975). Szczegółowy opis materiałów zaprezentowano w osobnym opracowaniu dotyczącym tego stanowiska (Bobrowski, Sobkowiak-Tabaka 2016). Poniżej zaprezentowano natomiast ogólną struk- 
turę inwentarzy krzemiennych w ramach poszczególnych wykopów, z uwzględnieniem frekwencji procentowej w dwóch największych - I/03 i II/03 (por. tabela 1). Natomiast ogólną strukturę w kategorii narzędzi w ramach wspomnianych wykopów przedstawiono w tabeli 2 .

Tabela 1. Kopanica, stan. 29, gm. Siedlec. Ogólna struktura ilościowa i procentowa artefaktów krzemiennych w ramach wykopów I/03, II/03 oraz ilościowa w wykopach III/03, IV/03 oraz WT I/03

Table 1. Kopanica, site 29, Siedlec Commune. General quantitative and percentage structure of flint artefacts in trenches I/03, II/03 and a quantitative structure in trenches III/03, IV/03 and WT I/03

\begin{tabular}{|c|c|c|c|c|c|c|c|}
\hline WYKOP & \multicolumn{2}{|c|}{$\mathrm{I} / 03$} & \multicolumn{2}{|c|}{$\mathrm{II} / 03$} & III/03 & IV/03 & WTI/03 \\
\hline Grupa/Kategoria & 1. & $\%$ & 1. & $\%$ & 1. & 1. & 1. \\
\hline \multicolumn{8}{|c|}{ I. Przygotowania rdzeni, zaprawy wstępnej rdzeni i wczesnej fazy rdzeniowania } \\
\hline 1. Odłupki korowe i ich fragmenty & 18 & 2,27 & 43 & 4,83 & - & 5 & - \\
\hline 2. Wióry korowe i ich fragmenty & 12 & 1,51 & 6 & 0,67 & - & - & - \\
\hline 6. Zatępce i podtępce pierwotne & 4 & 0,50 & - & - & - & - & - \\
\hline 7. Odłupki zaprawiakowe i ich fragmenty & 7 & 0,88 & 6 & 0,67 & - & - & - \\
\hline \multicolumn{8}{|c|}{ II. Eksploatacji odłupkowej } \\
\hline 1. Rdzenie odłupkowe jednopiętowe & 1 & 0,12 & 1 & 0,11 & 1 & - & 1 \\
\hline 2. Odłupki z rdzeni jednopiętowych i ich fragmenty & 47 & 5,94 & 46 & 5,16 & 2 & 5 & - \\
\hline 3. Rdzenie odłupkowe dwupiętowe & - & - & - & - & - & 1 & - \\
\hline 4. Odłupki z rdzeni dwupiętowych i ich fragmenty & 9 & 1,13 & 4 & 0,44 & - & 1 & - \\
\hline 5. Rdzenie odłupkowe ze zmienioną orientacją & 1 & 0,12 & 1 & 0,11 & - & - & - \\
\hline $\begin{array}{l}\text { 6. Odłupki z rdzeni ze zmienioną orientacją i ich } \\
\text { fragmenty }\end{array}$ & 14 & 1,76 & 20 & 2,24 & - & 2 & - \\
\hline \multicolumn{8}{|c|}{ III. Eksploatacji wiórowej } \\
\hline 1. Rdzenie wiórowe jednopiętowe & 1 & 0,12 & - & - & - & - & 1 \\
\hline 2. Wióry z rdzeni jednopiętowych $\mathrm{i}$ ich fragmenty & 83 & 10,49 & 90 & 10,11 & 9 & 15 & - \\
\hline 3. Rdzenie wiórowe dwupiętowe & - & - & 1 & 0,11 & - & - & - \\
\hline 4. Wióry $\mathrm{z}$ rdzeni dwupiętowych $\mathrm{i}$ ich fragmenty & 9 & 1,13 & 8 & 0,89 & - & - & - \\
\hline 5. Rdzenie wiórowe ze zmienioną orientacją & 2 & 0,25 & 1 & 0,11 & 1 & - & - \\
\hline $\begin{array}{l}\text { 6. Wióry z rdzeni o zmienionej orientacji i ich } \\
\text { fragmenty }\end{array}$ & 16 & 2,02 & 5 & 0,56 & 1 & - & - \\
\hline \multicolumn{8}{|c|}{ V. Napraw } \\
\hline 1. Świeżaki & 2 & 0,25 & 1 & 0,11 & - & - & - \\
\hline 2. Odnawiaki & 2 & 0,25 & - & - & - & - & - \\
\hline 3. Zatępce i podtępce wtórne & 1 & 0,12 & 5 & 0,56 & - & - & - \\
\hline \multicolumn{8}{|c|}{ VI. Okazów nieokreślonych, odpadków rdzeniowania i łuskania } \\
\hline 1. Rdzenie nieokreślone i ich fragmenty & 8 & 1,01 & 5 & 0,56 & - & - & - \\
\hline 2. Odłupki nieokreślone & 21 & 2,65 & 19 & 2,13 & - & - & - \\
\hline 3. Wióry nieokreślone & 5 & 0,63 & 10 & 1,12 & - & 4 & - \\
\hline 4. Luski (okrzeski) & 285 & 36,03 & 357 & 40,11 & 43 & 105 & - \\
\hline 5. Okruchy & 207 & 26,16 & 228 & 25,61 & 27 & 105 & 1 \\
\hline
\end{tabular}




\begin{tabular}{|c|c|c|c|c|c|c|c|}
\hline \multirow{2}{*}{$\begin{array}{c}\text { WYKOP } \\
\text { Grupa/Kategoria }\end{array}$} & \multicolumn{2}{|c|}{$\mathrm{I} / 03$} & \multicolumn{2}{|c|}{ II/03 } & \multirow{2}{*}{$\frac{\mathrm{III} / 03}{1 .}$} & \multirow{2}{*}{$\frac{\mathrm{IV} / 03}{1 .}$} & \multirow{2}{*}{$\frac{\mathrm{WTI} / 03}{1 .}$} \\
\hline & \multicolumn{2}{|c|}{1.} & \multirow{2}{*}{1.} & $\%$ & & & \\
\hline \multicolumn{7}{|c|}{ VII. Narzędzi i charakterystycznych odpadów z ich produkcji } & \\
\hline 1. Narzędzia & 34 & 2,9 & 30 & 3,37 & 2 & 8 & 1 \\
\hline 3. Mikrorylce (rylcowce) & 1 & 0,12 & 2 & 0,22 & - & 1 & - \\
\hline \multicolumn{8}{|c|}{ VIII. Surowca nieobrabianego } \\
\hline 1. Bryłki surowca & - & - & 1 & 0,11 & - & - & - \\
\hline \multicolumn{8}{|c|}{ IX. Narzędzi produkcji krzemieniarskiej } \\
\hline 1. Podkładki & 1 & 0,12 & - & - & - & - & - \\
\hline SUMA & 791 & $\sim 100$ & 890 & $\sim 100$ & 86 & 252 & 4 \\
\hline
\end{tabular}

Tabela 2. Kopanica, stan. 29, gm. Siedlec. Ogólna struktura ilościowa i procentowa narzędzi w ramach wykopów I/03, II/03 oraz ilościowa w wykopach III/03, IV/03 oraz WT I/03

Table 2. Kopanica, site 29, Siedlec Commune. General quantitative and percentage structure of tools in trenches I/03, II/03 and a quantitative structure in trenches III/03, IV/03 and WT I/03

\begin{tabular}{|l|c|c|c|c|c|c|c|}
\hline \multirow{2}{*}{ Typy narzędzi } & \multicolumn{2}{|c|}{$\mathrm{I} / 03$} & \multicolumn{2}{|c|}{ II/03 } & III/03 & IV/03 & WT/03 \\
\cline { 2 - 10 } & 1. & $\%$ & 1. & $\%$ & 1. &. &. \\
\hline Drapacze & 3 & 9,09 & 2 & 6,66 & - & - & - \\
\hline Skrobacze & 5 & 15,15 & 3 & 9,99 & - & - & - \\
\hline Przekłuwacze & 1 & 3,03 & 1 & 3,33 & - & - & - \\
\hline Wiertniki & 1 & 3,03 & 1 & 3,33 & - & - & - \\
\hline Obłęczniki & 2 & 6,06 & 2 & 6.66 & - & - & 1 \\
\hline Narzędzia zębate & - & - & - & - & - & 1 & - \\
\hline Trapezy & 7 & 21,21 & 4 & 13,33 & - & 2 & - \\
\hline Tylczaki & 1 & 3,03 & 2 & 6,66 & - & 1 & - \\
\hline Wióry tylcowe & - & - & - & - & - & 1 & - \\
\hline Trójkąty & - & - & - & - & - & 1 & - \\
\hline Nieokreślone fragmenty zbrojników & 1 & 3,03 & - & - & - & - & - \\
\hline Piki & 1 & 3,03 & - & - & - & - & - \\
\hline Ciosaki & - & - & 1 & 3,33 & - & - & - \\
\hline Odłupki retuszowane & 7 & 21,21 & 4 & 13,33 & - & 1 & - \\
\hline Wióry retuszowane & 3 & 9,09 & 7 & 23,33 & 2 & - & - \\
\hline Inne & 1 & 6,06 & 3 & 9,99 & - & 1 & - \\
\hline SUMA & 33 & $\sim 100$ & 30 & $\sim 100$ & 2 & 8 & 1 \\
\hline
\end{tabular}

Niemal 100\% określonego surowca użytego w produkcji krzemieniarskiej na stanowisku to lokalny, nie najlepszej jakości narzutowy krzemień kredowy bałtycki odmiany nieotoczakowej. Występuje on w licznych odmianach, różniących się od siebie barwą, połyskiem, stopniem zmatowienia czy przeźroczystości oraz spatynowania. Najczęściej spotka się krzemienie w różnych odcieniach szarości od jasno- 
szarego, białawego, przez szary i ciemnoszary, do prawie czarnego, a także krzemień lekko zmatowiony o barwie od jasnopiaskowej i kremowej, do jasnobrązowej. Wyjątkiem jest znaleziony w wykopie II/03 trapez wykonany z krzemienia czekoladowego. Około 30\% wytworów rejestrowanych w wykopach I/03, II/03 i III/03 nosiło ślady silnego przegrzania w ogniu, uniemożliwiające jednoznaczną identyfikację surowca. W wykopie IV/03 udział okazów przegrzanych w ogniu przekraczał 52\%.

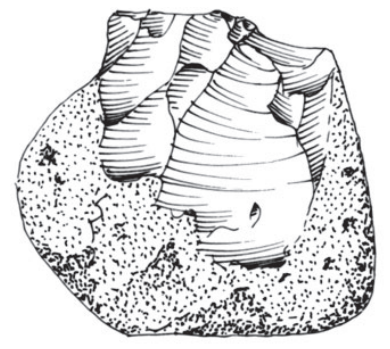

1

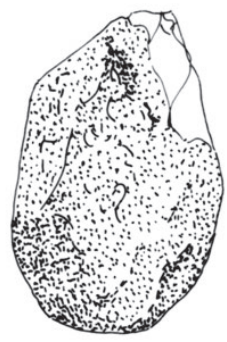

1

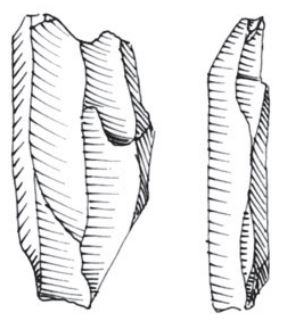

3

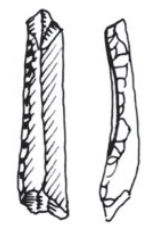

5
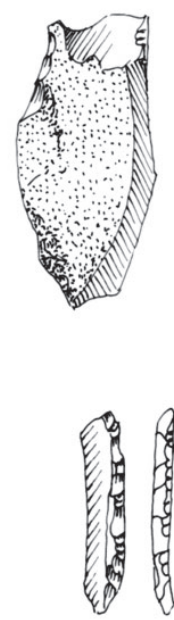

6

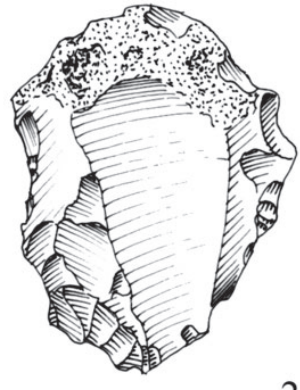

2

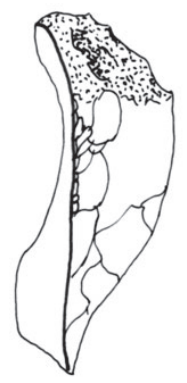

(1)
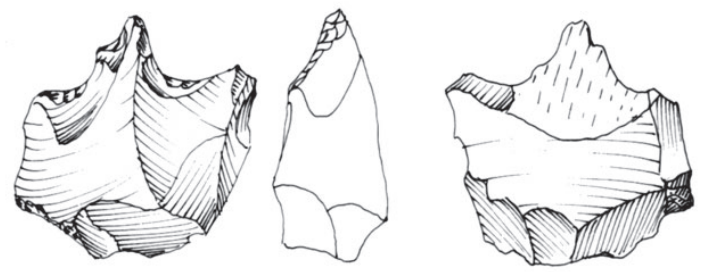

4

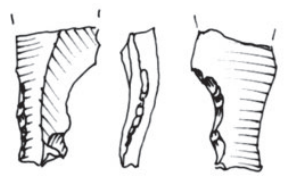

7

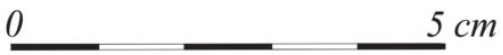

Ryc. 8. Kopanica, stan. 29, gm. Siedlec. Artefakty krzemienne z powierzchni i wykopów sondażowych. 1,3 - rdzenie, 2 - drapacz, 4 - narzędzie kombinowane, 5 - trójkąt, 6 - tylczak, 7 - liściak ahrensburski (rys. J. Sawicka)

Fig. 8. Kopanica, site 29, Siedlec Commune. Flint artefacts from the surface and test excavations. 1,3 - cores, 2 - endscraper, 4 - combined tool, 5 - triangle, 6 - backed piece, 7 - Ahrensburgian tanged point (drawn by J. Sawicka) 

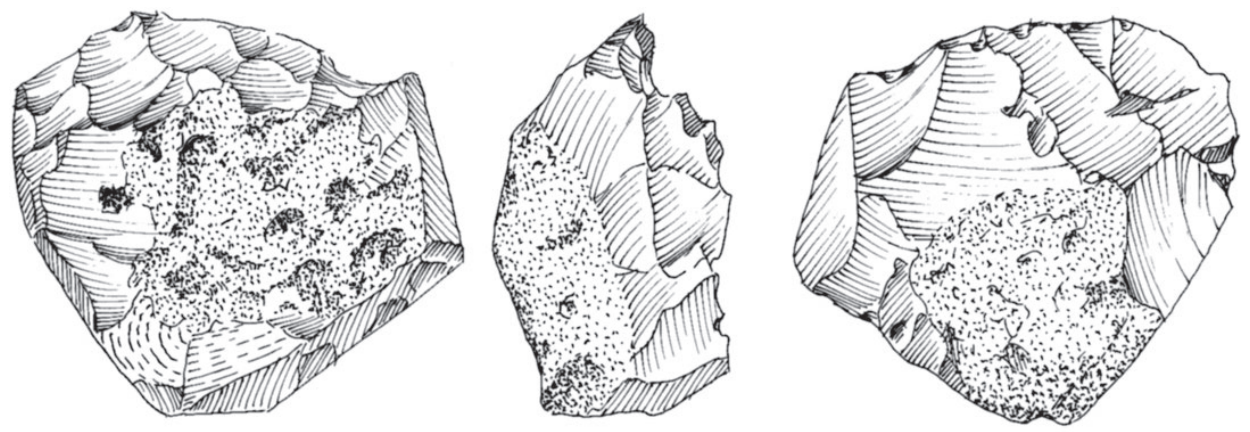

1

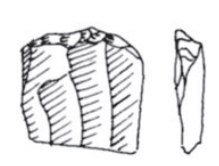

2
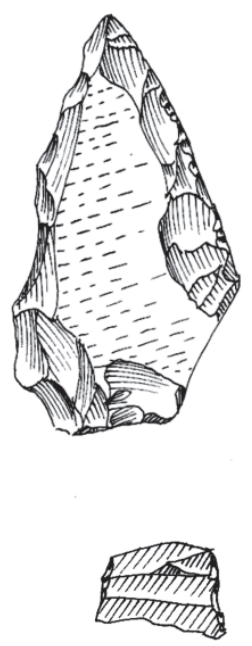

7
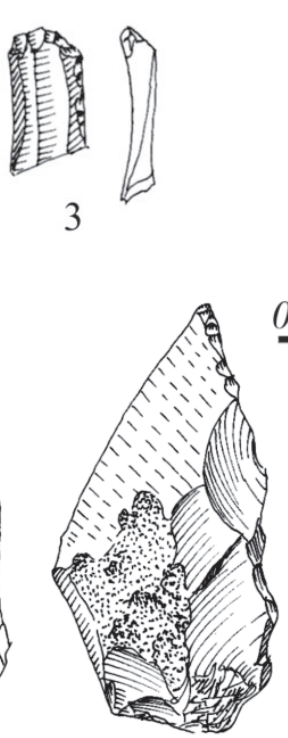

5

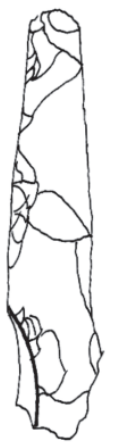

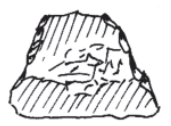

8
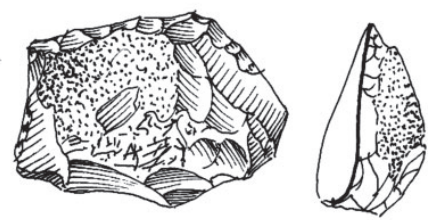

4

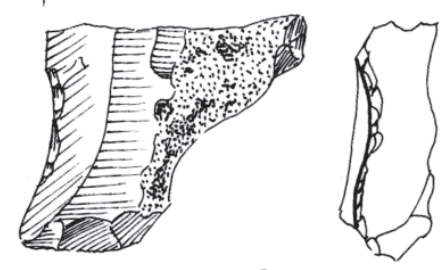

6

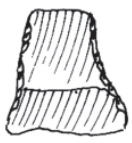

9

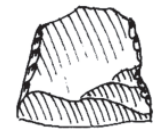

10

Ryc. 9. Kopanica, stan. 29, gm. Siedlec. Wykop I/03. 1 - rdzeń, 2-3 - drapacze, 4 - skrobacz, 5 - pik, 6 - liściak typu Lyngby, 7-10 - trapezy (rys. J. Sawicka)

Fig. 9. Kopanica, site 29, Siedlec Commune. Trench I/03. 1 - core, 2-3 - endscrapers, 4 - scraper, 5 - pick, 6 - Lyngby point, 7-10 - trapezes (drawn by J. Sawicka) 
Sądząc po wielkości wytworów znalezionych na stanowisku, użytkowano na ogół niewielkie bryłki surowca lub okruchy powstałe w wyniku spękania większych brył, o średnicy z rzadka przekraczającej 50-60 mm. Na ponad 2000 analizowanych wytworów krzemiennych zaledwie kilka miało nieznacznie większe wymiary. W ramach wykopu II/03 zarejestrowano bryłkę surowca o wymiarach $84 \times 30 \times 25 \mathrm{~mm}$. W wykopie PT I/03 wystąpił rdzeń o wymiarach $62 \times 42 \times 42 \mathrm{~mm}$ (ryc. 11:5), a w wykopie I/03 odnawiak o wymiarach $75 \times 56 \times 25 \mathrm{~mm}$ oraz drapacz wiórowy o wymiarach $65 \times 32 \times 13 \mathrm{~mm}$. Zabytki te zarówno wielkością, jak i charakterem odbiegają od zdecydowanej większości rejestrowanych na stanowisku artefaktów krzemiennych i należy je zapewne wiązać ze starszym osadnictwem schyłkowopaleolitycznym na stanowisku. Niemal wszystkie rdzenie znalezione na stanowisku były maksymalnie wykorzystane (do wyjątkowych należał mały rdzeń zaczątkowy - ryc. 8:1). Największe z nich miały wymiary $42 \times 30 \times 16 \mathrm{~mm}$ (ryc. 9:1) i $41 \times 31 \times 22 \mathrm{~mm}$ (ryc. 10:1). Największe okazy debitażu to pojedyncze odłupki korowe o średnicy około $47 \mathrm{~mm}$ czy zatępiec wtórny o wymiarach $42 \times 10 \times 8 \mathrm{~mm}$ (wykop II/03). Wśród wiórów i odłupków dominują zdecydowanie okazy drobne, prawie mikrolityczne. Jakość surowca miała znaczny wpływ na wielkość półsurowca i gotowych narzędzi.

Analiza technologiczno-typologiczna artefaktów krzemiennych z poszczególnych wykopów nie wykazała większych różnic między nimi. Na łączną liczbę około 2020 wytworów krzemiennych, zarejestrowanych w ramach wykopów badawczych, okazy nieokreślone, odpadki rdzeniowania i łuskania (grupa technologiczna VI) stanowiły od $69 \%$ w wykopie II/03, przez $73 \%$ w wykopie I/03, po około $82 \%$ w wykopach III/03 i IV/03. Pozostałe okazy analizowanego zbioru w całości stanowiły artefakty eksploatowane techniką klasycznego rdzeniowania. W zbiorach materiałów ze wszystkich wykopów zaobserwowano względną równowagę w posługiwaniu się techniką wiórową i odłupkową, przy nieznacznej przewadze tej pierwszej. Rzeczywisty obraz może zakłócać relatywnie duża frekwencja fragmentów wiórów. W celu uzyskania półsurowca eksploatowano głównie rdzenie jednopiętowe (ryc. 9:1, 11:1), czego dowodem jest ogromna przewaga półsurowca odbitego właśnie tą techniką - zarówno wiórów, jak i odłupków.

Udział odłupków z rdzeni jednopiętowych wśród wszystkich odłupków wynosi W wykopie I/03 - 38\%, a wiórów 64\%. W wykopie II/03 odpowiednio odłupków $33 \%$ i wiórów 78\%. Obserwacje makroskopowe analizowanych zabytków pokazują stosowanie przy zaprawie, obróbce i eksploatacji rdzeni używanie przede wszystkim twardego tłuka. Tylko nieliczne okazy debitażu i rdzeni noszą ślady stosowania techniki naciskowej. W produkcji półsurowca stosowano zabieg zmiany orientacji rdzenia. Większość rdzeni o zmienionej orientacji było przeróbką wcześniejszych form jednopiętowych (ryc. 10:1). Częsta zmiana orientacji rdzeni oraz niewielki udział w obróbce krzemieniarskiej rdzeni dwupiętowych również świadczy o deficycie dobrej jakości surowca. Także większość rdzeni nosiła ślady eksploatacji drob- 

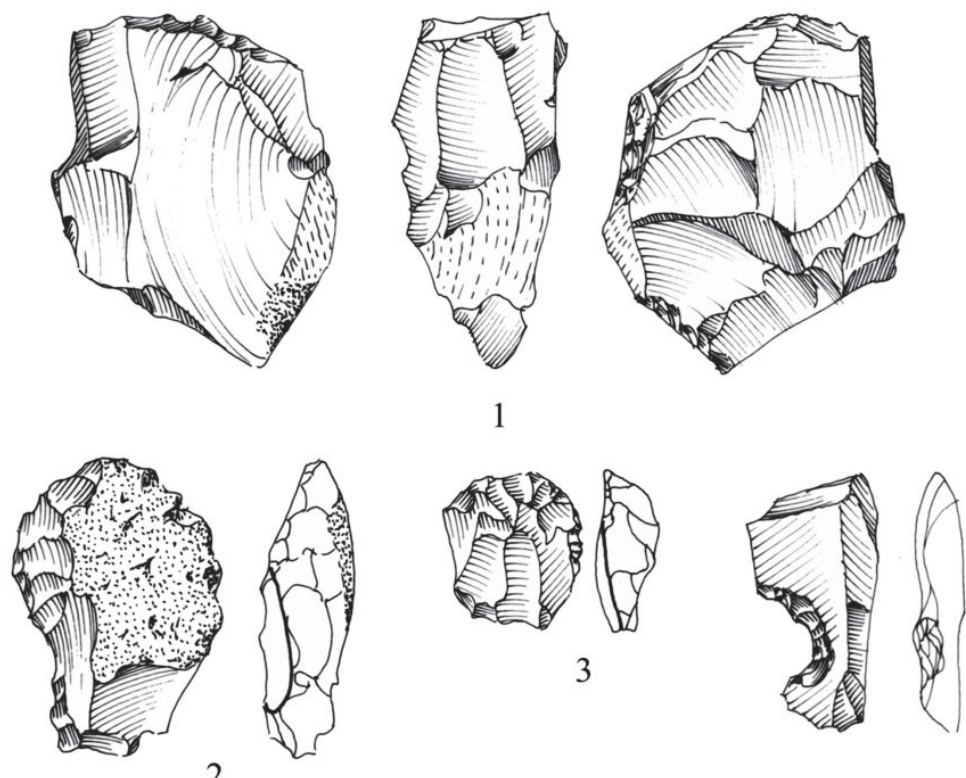

2
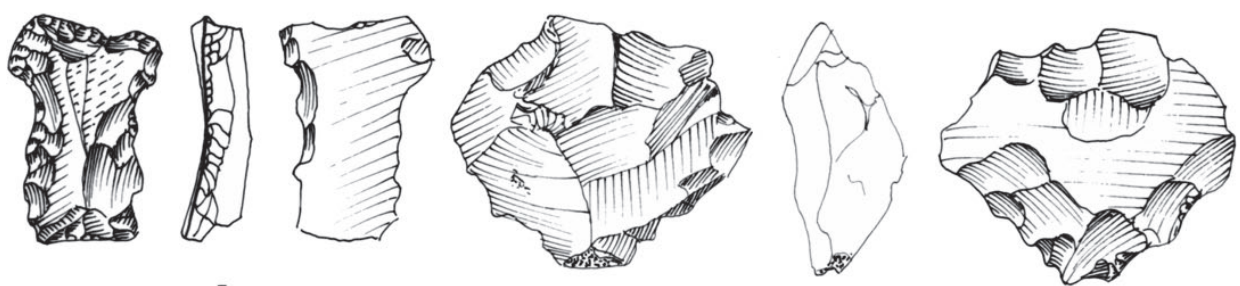

5

6

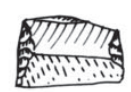

7

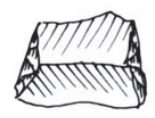

8

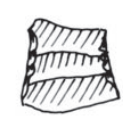

9

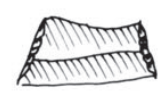

10

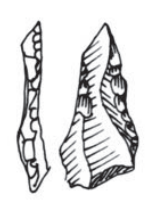

11

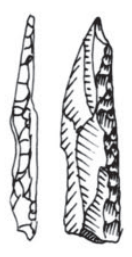

12

Ryc. 10. Kopanica, stan. 29, gm. Siedlec. Wykop II/03. 1 - rdzeń, 2-3 - drapacze, 4-5 - obłęczniki, 6 - ciosak, 7-10 - trapezy, 11-12 - tylczaki Stawinoga (rys. J. Sawicka)

Fig. 10. Kopanica, site 29, Siedlec Commune. Trench II/03. 1 - core, 2-3 - endscrapers, 4-5 - notches, 6 - tranchet, 7-10 - trapezes, 11-12 - Stawinoga backed bladelets (drawn by J. Sawicka)

nego półsurowca. Stosunkowo duża ilość odłupków korowych i innych okazów z grupy przygotowania rdzeni, zaprawy wstępnej rdzeni i wczesnej fazy rdzeniowania może świadczyć, że etap przygotowania rdzeni mógł być częściowo przeprowa- 
dzony na stanowisku. Zwłaszcza w wykopie II/03 udział odłupków korowych był duży i wynosił 31\% (wszystkich odłupków), a wiórów 9\% (wszystkich wiórów). Był on dwukrotnie większy niż w wykopie I/03. Być może w tej części stanowiska proces produkcyjny był bardziej intensywny. Część przygotowanych rdzeni była przyniesiona na stanowisko i natychmiast wykorzystana do produkcji półsurowca i narzędzi. Na stanowisku dokonywano też napraw rdzeni, o czym świadczą nieliczne charakterystyczne odpady (odnawiaki, świeżaki i zatępce). Stosowana była też technika mikrorylcowcza, czego dowodzą pojedyncze okazy mikrorylców.

Wśród 75 narzędzi zarejestrowanych w wykopach w Kopanicy wyróżniono różnorodne drapacze, zarówno formy odłupkowe (ryc. 10:2-3), jak i wiórowe (w tym okazy mikrolityczne (ryc. 9:2,3) i skrobacze (ryc. 9:4), wiertniki, przekłuwacze i obłęczniki (ryc. 8:4, 10:5). Najbardziej diagnostycznymi formami były zbrojniki, takie jak: mikrotylczaki typu Stawinoga (ryc. 10:11-12) i łukowe, trapezy (zarówno wysokie, jak i niskie - ryc. 9:7-10, 10:7-10, 11:2-3) oraz narzędzia makrolityczne, jak pik (ryc. 9:5) i ciosak (ryc. 10:6). Do produkcji zdecydowanej większości narzędzi (przede wszystkim zbrojników) stosowano przede wszystkim półsurowiec wiórowy. Natomiast odłupki i okruchy były używane głównie do przygotowania form narzędzi makrolitycznych (drapacze, skrobacze, ciosak, pik itp.).

\section{CHRONOLOGIA OSADNICTWA}

Bazując na pozyskanych w trakcie badań powierzchniowych i wykopaliskowych artefaktach krzemiennych, można wnioskować o dwóch etapach zasiedlenia stanowiska w epoce kamienia. O krótkotrwałym efemerycznym pobycie schyłkowopaleolitycznych łowców - zbieraczy technokompleksu z liściakami (zapewne w młodszym Dryasie ${ }^{4}$ ) świadczyć mogą trzonek liściaka bez łuskania strony spodniej trzonka (ahrensburskiego) znaleziony na powierzchni stanowiska (ryc. 8:7) oraz fragment liściaka typu Lyngby, zarejestrowany w wykopie I/03 (ryc. 9:6). Nie można wykluczyć związku z tym osadnictwem pojedynczych okazów niedystynktywnych okazów, jak np. masywnego drapacza znalezionego w wykopie I/03 oraz rdzenia jednopiętowego wiórowego zarejestrowanego w górnej warstwie wykopu torfowego (ryc. 11:5), odbiegających zarówno metrycznie, jak i technologicznie od większości rejestrowanych na stanowisku form oraz części debitażu.

Zdecydowanie bardziej intensywne i czytelne są pozostałości osadnictwa społeczności łowiecko-zbierackich okresu mezolitu. Rejestrowany zarówno na po-

\footnotetext{
${ }^{4} \mathrm{Z}$ rdzenia osadów biogenicznych, pobranego tuż przy stanowisku w $2015 \mathrm{r}$. z poziomu $461-459 \mathrm{~cm}$ (licząc od współczesnej powierzchni) pozyskano drobne węgle drzewne datowane radiowęglowo na $10470 \pm 60$ BP (Poz-76625). Oznaczenie wieku zostało sfinansowane ze środków projektu badawczego nr 12H 12020881, finansowanego przez Ministerstwo Nauki i Szkolnictwa Wyższego.
} 

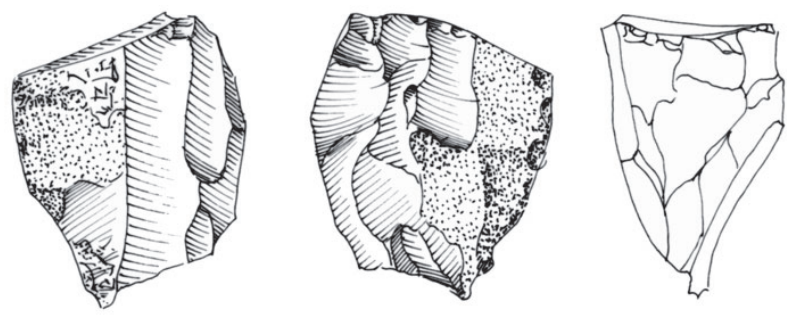

1

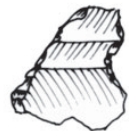

2

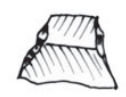

3

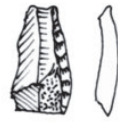

4
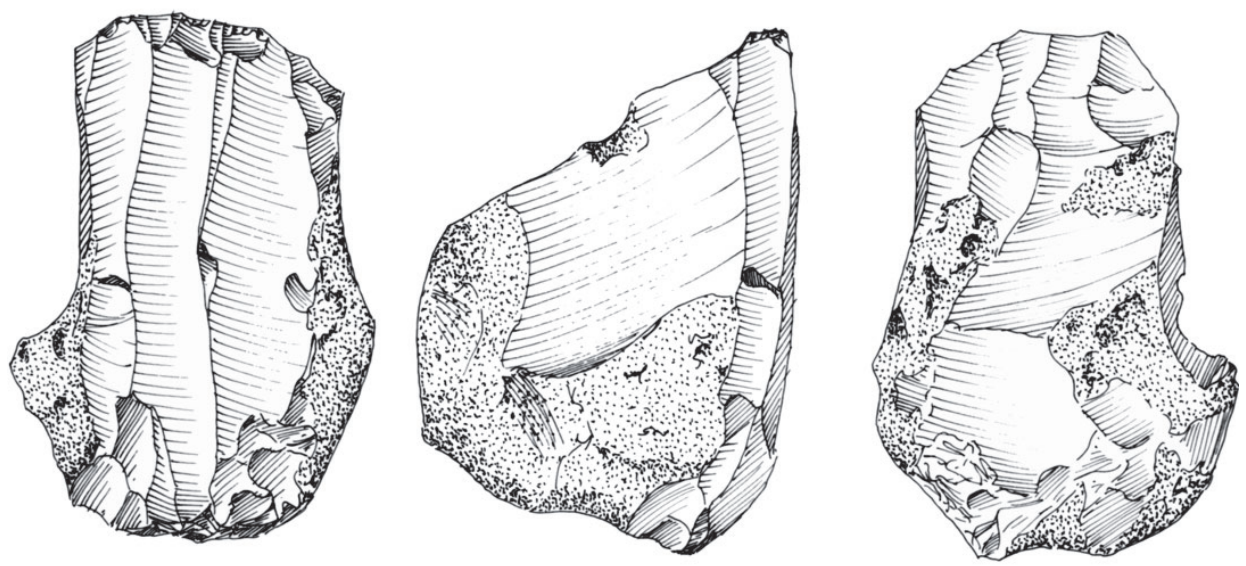

5

0 $5 \mathrm{~cm}$

Ryc. 11. Kopanica, stan. 29, gm. Siedlec. Wykop III/03. 1 - rdzeń; Wykop IV/03. 2-3 - trapezy, 4 - trójkąt; Wykop WTI/03. 5 - rdzeń (rys. J. Sawicka)

Fig. 11. Kopanica, site 29, Siedlec Commune. Trench III/03. 1 - core; Trench IV/03. 2-3 - trapezes, 4 - triangle; Trench WTI/03. 5 - core (drawn by J. Sawicka)

wierzchni stanowiskach, jak i w poszczególnych wykopach badawczych inwentarz krzemienny charakteryzuje się nie tylko olbrzymią jednorodnością surowcową, technologiczną i typologiczną, ale również obecnością charakterystycznych form narzędzi w postaci drapaczy (formy mikrolityczne), skrobaczy, narzędzi makrolitycznych (pika i ciosaka), zbrojników oraz pojedynczych okazów związanych $\mathrm{z}$ techniką mikrorylcowczą. Zarejestrowane na stanowisku narzędzia pojedynczo nie 
stanowią dobrych wyznaczników chronologiczno-kulturowych. Przykładem może być obecność takich elementów, jak: mikrotylczaki typu Stawinoga, pierwotnie wiązanych ze starszym odcinkiem mezolitu, tzw. cyklem narwiańskim (Więckowska 1975, s. 352) bądź kulturą komornicką datowaną na 7500-5900 lat BC (Kozłowski, Kozłowski 1977, s. 218). Margines chronologiczny występowania tego typu tylczaków jest jednak znacznie szerszy. Zbrojniki tego typu pojawiły się bowiem już w schyłkowym paleolicie, ale występowały także w zespołach późnomezolitycznych (Galiński 2002, s. 14, 204). Najbardziej dystynktywnym elementem pozwalającym na bardziej precyzyjne datowanie osadnictwa jest występowanie w zespole trapezów, dominujących w grupie zbrojników. Pojawienie się tego charakterystycznego typu zbrojników datowane jest na okres po 6000 lat BC (Kozłowski, Kozłowski 1977, s. 223; Galiński 2002, s. 71, 205). Fakt ten przyjmuje się jako jeden z głównych wyznaczników nowego okresu, zwanego młodszym lub późnym mezolitem, przypadającego na okres atlantycki (Kobusiewicz 1999, s. 92). O relatywnie młodym wieku tego inwentarza świadczyć może również obecność wśród trapezów okazu wykonanego z krzemienia czekoladowego. Import tego surowca jest znany choćby ze stanowisk datowanych na starszy mezolit (np. por. Bobrowski 1996). W zespołach Polski północno-zachodniej udział artefaktów z krzemienia czekoladowego wzrasta w póź-

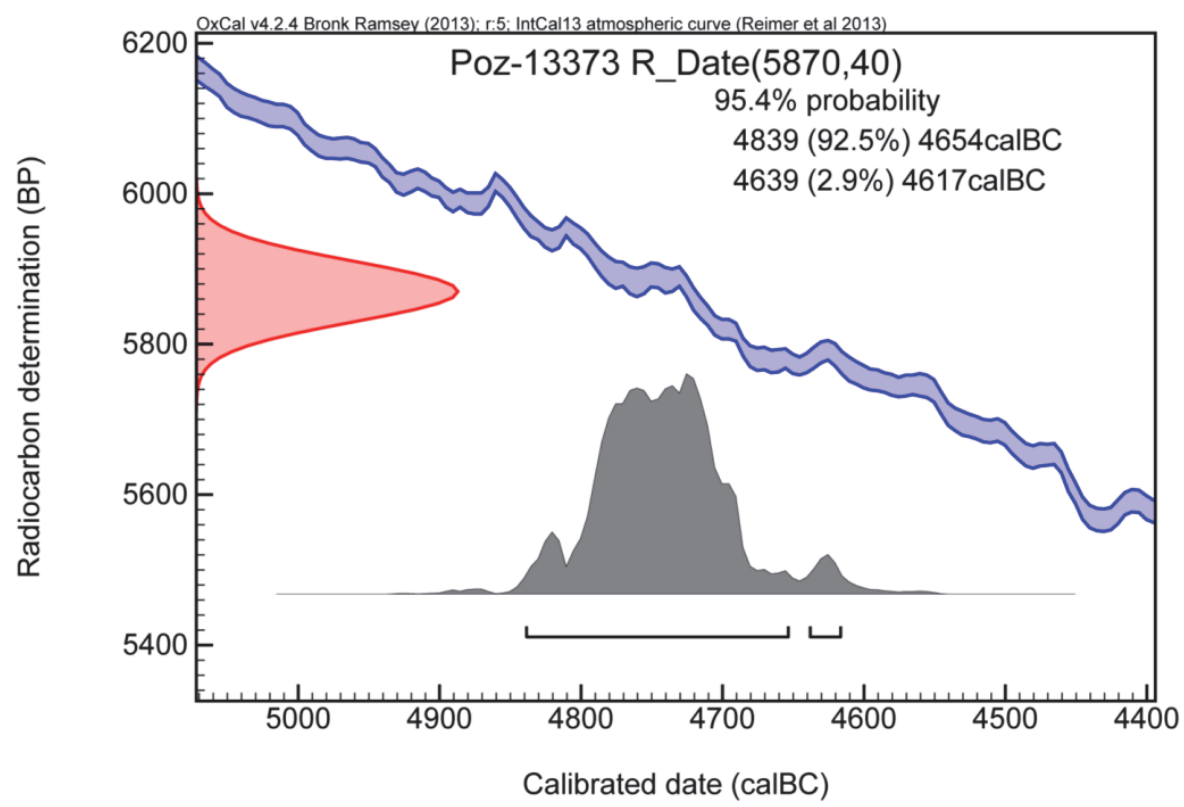

Ryc. 12. Kopanica, stan. 29, gm. Siedlec. Oznaczenie radiowęglowe przepalonych kości po kalibracji za pomocą programu OxCal v. 4.2.3 (Bronk Ramsey, Lee 2013), https://c14.arch.ox.ac.uk/oxcal/ OxCal.html Fig. 12. Kopanica, site 29, Siedlec Commune. Radiocarbon determination of burnt bones after calibration using OxCal programme v. 4.2.3 (Bronk Ramsey, Lee 2013), https://c14.arch.ox.ac.uk/oxcal/OxCal.html 
nym mezolicie. Jest to zapewne odzwierciedleniem bardziej intensywnej eksploatacji, użytkowania i dystrybucji tego surowca w tym okresie (por. Więckowska 1975, s. 410; Schild 2001). Inwentarz krzemienny z Kopanicy odpowiada najbardziej zespołom społeczności kultury chojnicko-pieńkowskiej lub inaczej nazywanych postmaglemoską (Kozłowski, Kozłowski 1977, s. 226-232) czy też maglemoską (Galiński 2002, s. 166-167; 2007, s. 197). Oprócz wspomnianych form narzędziowych także rdzenie znalezione na stanowisku są charakterystyczne dla technologii ugrupowań społeczności postmaglemoskich, o czym świadczy obecność różnorodnych form rdzeniowych, a w tym najbardziej rozpowszechnionych rdzeni jednopiętowych, wiórowych, wiórkowych i wiórowo-odłupkowych oraz duże zróżnicowanie półsurowca pod względem morfologicznym i metrycznym.

Potwierdzeniem względnej pozycji chronologicznej analizowanego zespołu jest wynik oznaczenia radiowęglowego wieku przepalonej kości zwierzęcej zdeponowanej w obiekcie mieszkalnym (por. wyżej). Wynosi ono 5870 440 BP (Poz-1337), a kalibrację wyniku za pomocą programu OxCal v. 4.2.3 (Bronk Ramsey, Lee 2013) przedstawiono na rycinie 12 . Otrzymany wynik pozwala synchronizować osadnictwo na stanowisku z okresem atlantyckim (AT3) wg L. Starkela i in. (2013).

\section{PODSUMOWANIE}

Z początkiem okresu atlantyckiego dochodzi do intensyfikacji osadnictwa mezolitycznego na terenie Niziny Środkowoeuropejskiej, wywołanej migracją społeczności łowiecko-zbierackich z terenów zalanych przez wody Morza Północnego i Bałtyckiego (Kabaciński 2008, s. 131). Spośród kilkuset znanych z terenu Wielkopolski stanowisk późnomezolitycznych zaledwie około 20 zespołów było pozyskanych na drodze badań wykopaliskowych. Jednym $z$ takich przykładów jest obozowisko łowców-zbieraczy z Kopanicy. Stanowisko to jest jednym z nielicznych późnomezolitycznych stanowisk ,piaskowych” w północno-zachodniej Polsce, które dostarczyło możliwości bezpośredniego oznaczenia wieku osadnictwa (przepalona kość zwierzęca).

Podobnie, czyli na 2. połowę okresu atlantyckiego datowane są radiowęglowo zespoły ze stanowisk 6 w Męcikale, pow. chojnicki (Bagniewski 1987, s. 114) czy Czeladzi Wielkiej, stan. I (Bagniewski 1977). Oznaczenia te wykonane zostały $\mathrm{z}$ drobnych węgli drzewnych.

Inwentarz krzemienny z obozowiska późnomezolitycznych łowców-zbieraczy społeczności postmaglemoskiej z Kopanicy znajduje liczne analogie na stanowiskach północno-zachodniej Polski, w tym także na stanowiskach położonych stosunkowo blisko, w tym samym mikroregionie osadniczym (Region Wojnowo). Wśród nich wymienić można stanowiska Smolno Wielkie 1 i 2, Wojnowo 1, położone kilkadziesiąt km dalej na południowy-zachód stanowisko w Pomorsku 1 (por. 
Kobusiewicz 1970, 1999, s. 103-105) czy oddalone około 90 km na wschód stanowisko $21 \mathrm{w}$ Puszczykowie, gm. loco, zlokalizowane na styku Pradoliny Warszawsko-Berlińskiej i Przełomowym Odcinku Warty (Krzyszowski 1997).

O intensywnym zasiedleniu rynny jezior zbąszyńskich (zwłaszcza na jej ujściowym odcinku do Pradoliny Warszawsko-Berlińskiej) świadczą również liczne schyłkowoplejstoceńskie i wczesnoholoceńskie stanowiska łowców-zbieraczy, odkryte w trakcie programu Archeologicznego Zdjęcia Polski i wcześniejszych badań (por. Bobrowski 2000; Kobusiewicz 1999, tab. 9-10).

\section{BIBLIOGRAFIA}

Bagniewski Z.

1977 Mezolityczne obiekty mieszkalne i gospodarcze z terenu Polski południowo-zachodniej. Archeologia Polski, 22(1), s. 35-70.

Bagniewski Z.

1979 Wyniki badań archeologicznych przeprowadzonych w rejonie Swornegaci, gm. Brusy, woj. bydgoskie. Śląskie Sprawozdania Archeologiczne, 20, s. 21-29.

Bagniewski Z.

1987 Mezolityczne społeczności myśliwsko-rybackie południowej części Pojezierza Kaszubskiego. Studia Archeologiczne, 17, Wrocław.

Bagniewski Z.

1999 Mezolityczna enklawa osadnicza na Polanie Łęczyckiej (Pojezierze Dobiegniewskie). Wrocław: Uniwersytet Wrocławski.

Bronk Ramsey C., Lee S.

2013 Recent and planned development of the program OxCal. Radiocarbon, 55, s. 3-4.

Brzozowski J., Siemaszko J.

1995 The Mesolithic site at Miłuki - research results. W: Recent Research on the Stone and Early Bronze Ages in the South-eastern Subbalticum: Papers of International Conference. Supraśl (Poland), September 1994.

Bobrowski P.

1996 Stanowisko mezolityczne Wojnowo, stan. 3, gm. Kargowa, woj. zielonogórskie. Wielkopolskie Sprawozdania Archeologiczne, 4, s. 5-22.

Bobrowski P.

$2000 \quad$ Inwentarze krzemienne $\mathrm{z}$ badań powierzchniowych stanowisk z epoki kamienia Ziemi Lubuskiej, Pojezierza Wielkopolskiego i Leszczyńskiego. Wielkopolskie Sprawozdania Archeologiczne, 5, s. 153-195.

Bobrowski P., Sobkowiak-Tabaka I.

2016 Kopanica, stan. 29, gm. Siedlec. W: M. Kobusiewicz (red.), 10 tysięcy lat osadnictwa w Regionie Wojnowa. Arkadia lowców-zbieraczy (w druku).

Domańska L.

1992 Udział komponentu maglemoskiego w rozwoju kulturowym późnomezolitycznych społeczeństw Pomorza w świetle badan na stanowisku Jastrzębia Góra 4, woj. Gdańsk. Acta Universitatis Lodziensis. Folia Archaeologica, 16, 61-69.

Galiński T.

1992 Mezolit Pomorza. Szczecin: Muzeum Narodowe w Szczecinie. 
Galiński T.

2002 Spoleczeństwa mezolityczne. Osadnictwo, gospodarka, kultura ludów towieckich w VIII-IV tysiacleciu p.n.e. na terenie Europy. Szczecin: Muzeum Narodowe w Szczecinie.

Galiński T.

2007 Rotnowo: stanowisko paleolityczne i mezolityczne $w$ dolinie Lubieszowej na Pomorzu Zachodnim. Warszawa: Instytut Archeologii i Etnologii PAN.

Jensen O.L.

2009 Dwellings and graves from the Late Mesolithic site of Nivå 10, eastern Denmark. W: S.B. McCarten, R. Schulting, G. Warren, P. Woodman (red.), Mesolithic Horizons. Papers presented at the Seventh 126 International Conference on the Mesolithic in Europe, Belfast, 2005 (s. 465-472). Oxford: Oxbow Books.

Kabaciński J.

2008 Lowcy - zbieracze epoki polodowcowej. W: M. Kobusiewicz (red.), Pradzieje Wielkopolski (s. 121-146). Poznań: Instytut Archeologii i Etnologii PAN.

Kabaciński J., Sobkowiak-Tabaka I.

2010 Osadnictwo mezolityczne. W: J. Kabaciński, I. Sobkowiak-Tabaka (red.), Materiaty do wczesnych pradziejów Zachodniej Wielkopolski. Osadnictwo późnopaleolityczne i mezolityczne na stanowisku 7 w Ośnie Lubuskim (s. 63-74). Poznań: Instytut Archeologii i Etnologii PAN.

Kobusiewicz M.

1970 Mezolit schyłkowy w środkowozachodniej Wielkopolsce. Światowit, 31(1969), s. 101-189. Kobusiewicz M.

1999 Ludy towiecko-zbierackie pótnocno-zachodniej Polski. Poznań: Wydawnictwo Poznańskiego Towarzystwa Przyjaciół Nauk.

Kobusiewicz M., Kabaciński J.

1991 Late Mesolithic dwelling object in Pomorsko (Western Poland). Przeglad Archeologicz$n y, 38$, s. 5-15.

Kondracki J.

2009 Geografia regionalna Polski. Warszawa: Wydawnictwo Naukowe PWN.

Kozłowski J.K., Kozłowski S.K.

1977 Epoka kamienia na ziemiach polskich. Warszawa: Państwowe Wydawnictwo Naukowe. Krzyszowski A.

1997 Obozowisko mezolityczne z pierwszej połowy okresu atlantyckiego w Puszczykowie, w województwie poznańskim. Fontes Archaeologici Posnaniesis, 38, s. 13-40.

Marciniak M.

1998 Pradzieje regionu brodnickiego. W: J. Drygała (red.), Brodnica siedem wieków miasta (s. 67-80). Brodnica: Rada Miejska w Brodnicy.

Ruta S.

1997 Materiały krzemienne z późnomezolitycznego stanowiska Jastrzębia Góra 4, województwo gdańskie. Acta Universitatis Lodziensis. Folia Archaeologica, 21, s. 7-30.

Schild R.

2001 Three reasons why it is likely that the early Mesolithic population in Poland was not aboriginal. W: B. Ginter, B. Drobniewicz, B. Kazior, M. Nowak, M. Połtowicz (red.), Problemy epoki kamienia na obszarze starego świata. Ksiega Jubileuszowa dedykowana Profesorowi Januszowi K. Kozłowskiemu (s. 229-233). Kraków: Uniwersytet Jagielloński.

Schild R., Marczak M., Królik H.

1975 Późny mezolit. Próba wieloaspektowej analizy otwartych stanowisk piaskowych. Wrocław - Warszawa - Kraków - Gdańsk: Zakład Narodowy im. Ossolińskich. 
Starkel L., Michczyńska D.J., Krąpiec M., Margielewski W., Nalepka D., Pazdur A.

2013 Progress in the Holocene chrono-climatostratigraphy of Polish territory. Geochronometria, 40(1), s. 1-21.

Więckowska H.

1975 Mezolit w Polsce. W: W. Chmielewski, W. Hensel (red.), Prahistoria ziem polskich (t. 1). Paleolit i mezolit (s. 345-409). Wrocław - Warszawa - Kraków - Gdańsk: Zakład Narodowy im. Ossolińskich.

\section{LATE MESOLITHIC SETTLEMENT AT KOPANICA, SITE 29, SIEDLEC COMMUNE}

\section{Sum mary}

Kopanica, site 29, is situated on the eastern edge of a former glacial trough. Now, it channels the Obra River north (the Northern Obra Channel) and is partly filled by Lakes Zbąszyńskie. The site lies at the north-western tip of the present village, roughly $1 \mathrm{~km}$ from its centre, $0.8 \mathrm{~km}$ north of the road from Kopanica to Wąchabno and $0.23 \mathrm{~km}$ from today's river channel. The area is located at the junction of two micro-regions: the so-called Zbąszyń Furrow and the Kargowa Basin.

The site was discovered in the 1990s in the course of AZP research (Archaeological Record of Poland (AZP 58-13 Working Area). Regular excavations were undertaken in 2003. Four trenches (I/03, II/03, III/03 and IV/03) were set on the fluvial terrace and a small peat trench (WT I/03) was dug out in the floodplain.

The northern edges of the trenches WT I/03, I/03 and II/03 formed one line, thus providing a $24 \mathrm{~m}$-long profile of the site along the WE axis.

In total, the trenches yielded slightly more than 2000 flint artefacts, several hundred pottery fragments attributable to the Lusatian culture and the modern period, a few bone fragments and a modern coin.

In the southern part of trench II/03, under humus, $25 \mathrm{~cm}$ from the surface, excavations uncovered an irregular and oval feature sized $220 \times 200 \mathrm{~cm}$ (feature 1). Shaped like an inverted trapezium (slightly asymmetrical) in cross-section, the feature was roughly $110 \mathrm{~cm}$ thick. Dug into the roof of the feature was an early medieval hearth (970 $330 \mathrm{BP}$; Poz-9015). Close to the hearth, we registered four postholes, $\mathrm{V}$ - shaped in cross section, measuring from 8 to $18 \mathrm{~cm}$ in diameter, and $10-60 \mathrm{~cm}$ in depth. Around feature 1 were 20 more postholes, spaced at regular intervals and forming roughly two outer rings. This regular arrangement of the postholes around feature 1 suggested the existence of some functional relationship between them. We believe that this was a dwelling structure, partly sunk into the ground, $3.6 \mathrm{~m}$ in diameter; if that is the case, the postholes would be the remains of the roof. A grouping of postholes on the NE side of the feature shows perhaps where the entrance was situated. Dwelling structures have been uncovered at approximately ten sites in the Polish Lowlands.

The dwelling structure yielded 77 flint artefacts (one retouched flake, five blades, seven flakes, and 64 small chips and chunks) and a fragment of a burnt animal bone. 
Artefacts recovered from all trenches were distributed evenly and did not form any distinct concentrations.

Almost all identified flint raw material was local, poor quality non-pebble variety of erratic Baltic Cretaceous flint, with one exception - a trapeze trench II/03, which was produced from chocolate flint. About $30 \%$ of flint artefacts recovered from trenches were heavily burnt, which prevented unequivocal identification of the raw material.

Judging by the size of the artefacts, people occupying the site used mostly small nuggets of local raw material or chunks from cracked lumps, rarely larger than $50-60 \mathrm{~mm}$ in diameter. Most common in the group of blades and flakes are tiny, almost microlithic specimens.

Technological and typological analyses of flint artefacts from particular trenches showed no major differences between them. Lumps of raw material were exploited using a classing flaking technique; the assemblages from all trenches demonstrate that blade and flake technologies were essentially equally common, with a slight predominance of the former. Blanks were mostly removed from single-platform cores, as evidenced by a huge predominance of blanks, both blades and flakes, detached using this technique. Macroscopic observations of the artefacts show that hard hammer was mostly used for core preparation, processing and exploitation. Fewer debitage pieces and cores evidence also the use of a pressure technique. Core orientation was changed when removing blanks. A relatively large number of cortical flakes and other specimens from core preparation, trimming and initial flaking group may possibly show that striking surfaces could be partly prepared on-site. A group of 75 implements recovered at Kopanica consists of a variety of endscrapers, scrapers, borers, perforators, notches, typical insets and finally macrolithic tools (picks and tranchets).

The flint artefacts recovered in the course of surface surveys and excavations suggests that the site was occupied twice in the Stone Age. Fragments (shafts) of an Ahrensburgian tanged point, a Lyngby point and a single-platform core from the peat trench attest to a short-time stay of a Late Palaeolithic community.

However, a hunter-gatherer Mesolithic community occupied site 29 at Kopanica much longer. The excavations produced typical Mesolithic tools, such as endscrapers, scrapers, macrolithic tools (a pick and a tranchet), insets and a few specimens that evidence the usage of the microburin technique. Most common among the insets, trapezes are the most distinctive element in the assemblage, allowing for its more precise dating. The trapezes are commonly viewed as chronological markers for the Late Mesolithic. In addition to the earlier-mentioned implements, also cores and blanks are typical of the technology of the Chojnice-Pieńków (post-Maglemose) culture of the Atlantic period. The relative chronology of the assemblage was further confirmed by the radiocarbon dating of a burnt animal bone deposited in the dwelling structure (5870 \pm 40 BP; Poz-1337).

Kopanica, site 29, is among a few Late Mesolithic 'sand' sites in north-western Poland, the chronology of which is anchored with absolute dates.

Translated by Agnieszka Tokarczuk 